\title{
Characteristics and Treatment of Wastewater from the Mercaptan Oxidation Process: A Comprehensive Review
}

\author{
Ernesto Pino-Cortés ${ }^{1, *} \mathbb{C}$, Silvio Montalvo ${ }^{2}$, César Huiliñir ${ }^{2}$, Francisco Cubillos ${ }^{2}$ \\ and Juan Gacitúa ${ }^{2}$ \\ 1 Escuela de Ingeniería Química, Pontificia Universidad Católica de Valparaíso, Av. Brasil 2162, Valparaíso \\ 2362854, Chile \\ 2 Departamento de Ingeniería Química, Universidad de Santiago de Chile, Av. Libertador Bernardo O'Higgins \\ 3363, Estación Central 9170022, Chile; silvio.montalvo@usach.cl (S.M.); cesar.huilinir@usach.cl (C.H.); \\ francisco.cubillos@usach.cl (F.C.); juan.gacitua@usach.cl (J.G.) \\ * Correspondence: ernesto.pino@pucv.cl; Tel.: +56-322372609
}

Received: 12 March 2020; Accepted: 31 March 2020; Published: 3 April 2020

\begin{abstract}
Sulfur compounds are removed from petroleum by the addition of sodium hydroxide at a very high concentration. As a result, a residue called spent soda or spent caustic is generated, being extremely aggressive to the environment. In this work, the chemical properties of this residue are described in detail. The sodium hydroxide remains that have not reacted, sulfur compounds, and organic matter are the primary pollutants reported. Additionally, the main characteristics of the methods of treatment used to reduce them are described. This review comes from comprehensive and updated research and bibliographic analysis about the investigation on the topic. The advantages and disadvantages of the different treatment methods are highlighted. We established some criteria to set out when assessing the application of each one of these treatments is considered.
\end{abstract}

Keywords: biological processes; electrochemical processes; oxidation processes; petroleum; phenols; sulfides

\section{Introduction}

Petroleum is around $85 \%$ carbon and $12 \%$ hydrogen, while in the remaining $3 \%$, we find several elements that consist mainly of oxygen, nitrogen, and sulfur. The sulfur compounds limit the direct use of petroleum in any of its forms, such as liquefied petroleum gas (LPG), due to its odorous, corrosive, and environmentally harmful characteristics. Different techniques or methods are necessary for the reduction of these compounds in petroleum. Among these sulfur compounds are mercaptans and sulfides. Mercaptans are thiols containing the functional group formed by a sulfur atom and a hydrogen atom (-SH). This functional group is called the thiol or sulfhydryl group. Examples of these compounds present in LPG are methylmercaptan $\left(\mathrm{H}_{3} \mathrm{C}-\mathrm{SH}\right)$ and ethylmercaptan $\left(\mathrm{H}_{5} \mathrm{C}_{2}-\mathrm{SH}\right)$.

The technology used globally for mercaptan removal content in the oil industry is the mercaptan oxidation (MEROX) process [1,2]. It is a catalytic conversion process in which mercaptans react to produce disulfides. It is promoted by a catalyst which activates the oxidation at room temperature, using atmospheric oxygen according to the following reactions:

Mercaptan $+\mathrm{NaOH}$ to form sodium mercaptan:

$$
\mathrm{RSH}+\mathrm{NaOH} \rightarrow \mathrm{RSNa}+\mathrm{H}_{2} \mathrm{O}
$$


Mercaptan oxidation to form disulfides $+\mathrm{NaOH}$ :

$$
\mathrm{RSNa}+\frac{1}{4} \mathrm{O}_{2}+\frac{1}{2} \mathrm{H}_{2} \mathrm{O} \rightarrow \mathrm{RSSR}+\mathrm{NaOH}
$$

As sodium hydroxide depletes as it reacts, its ability to remove sulfides and mercaptans also decreases. When the disulfides accumulate to a few milligrams per liter, the $\mathrm{OH}^{-}$content falls below $5 \%$, whereby this depleted soda solution is purged. Other causes of sodas depletion are the accumulation of mercaptans, $\mathrm{Na}_{2} \mathrm{~S}$, phenolic compounds, emulsified naphthalenes, thiosulfates, carbonates, and $\mathrm{Fe}^{+2}$ precipitates [2]. The $\mathrm{H}_{2} \mathrm{~S}$ and $\mathrm{CO}_{2}$ that are also present in the medium to be oxidized react with the caustic soda according to the following competitive reactions [3]:

$$
\begin{gathered}
\mathrm{H}_{2} \mathrm{~S}+2 \mathrm{NaOH} \rightarrow \mathrm{Na}_{2} \mathrm{~S}+2 \mathrm{H}_{2} \mathrm{O} \\
\mathrm{CO}_{2}+2 \mathrm{NaOH} \rightarrow \mathrm{Na}_{2} \mathrm{CO}_{3}+\mathrm{H}_{2} \mathrm{O}
\end{gathered}
$$

These side effects can cause several problems, such as the irreversible consumption of caustic soda, low absorbing mercaptans by the presence of sodium salts, and the precipitation of solid due to the accumulation of salt in the caustic solution. That is why a caustic solution purge and a fresh soda replenishment are provided to prevent salt accumulation $\left(\mathrm{Na}_{2} \mathrm{~S} / \mathrm{Na}_{2} \mathrm{CO}_{3}\right)$ from restoring the appropriate $\mathrm{NaOH}$ concentration. Spent caustic (SC) is the name of the solution obtained once the mercaptans react with $\mathrm{NaOH}$. Without adequate treatment, $\mathrm{SC}$ can cause environmental problems.

The main focus of this comprehensive review is to expose different techniques released and mentioned in the literature, to process the SC. The first approach is a brief description of its characteristics that explain the environmental problems caused by SC. Following, the main body of this paper has a series of processes that help neutralize sodas and allow their subsequent biological treatment. There is no review published before or paper that reports this relevant information that could help engineers to make better decisions in the petroleum industry. The analysis included information and results from reports, theses, and research articles published recently.

\section{SC Characteristics}

SC is classified into three types [4]: sulfidic (SSC), cresylic (SCC), and naphthenic (SNC). The composition of this type of waste is highly variable as can be seen in Table 1. SC solutions are characterized by high $\mathrm{pH}(\mathrm{pH}>12)[5]$ and high sodium concentrations up to $2 \%-15 \%(w / w)$. Conner et al. [6] also found that spent sulfidic caustics contained hydrosulfides (HS ${ }^{-}$) and sulfides ${ }^{2-}$ greater than $2 \%-3 \%(w / w)$.

Table 1. Main chemical components present in spent sodas.

\begin{tabular}{cccccc}
\hline Parameters & SMC & Sulfidic & Cresylic & Naphtenic & Reference \\
\hline \multirow{5}{*}{$\mathrm{pH}$} & - & $11-12.5$ & - & - & {$[7]$} \\
& - & $12-13.5$ & - & - & {$[8]$} \\
& - & $13.1-13.5$ & - & - & {$[9]$} \\
& $7.5-13$ & - & - & - & {$[10]$} \\
& - & $11.2-13$ & - & - & {$[5]$} \\
& - & $12-14$ & $12-14$ & $12-14$ & {$[11]$} \\
& - & $13.1-13.5$ & - & - & {$[12]$} \\
& - & $13-14$ & $12-14$ & $12-14$ & {$[13]$} \\
& - & $13-14$ & $12-14$ & $12-14$ & {$[14]$} \\
\hline
\end{tabular}


Table 1. Cont

\begin{tabular}{|c|c|c|c|c|c|}
\hline Parameters & SMC & Sulfidic & Cresylic & Naphtenic & Reference \\
\hline \multirow{12}{*}{$\begin{array}{c}\mathrm{COD} \\
\left(\mathrm{g} \mathrm{O}_{2} / \mathrm{L}\right)\end{array}$} & \multirow[t]{4}{*}{-} & $7.5-60$ & - & - & [7] \\
\hline & & $60.3-68.1$ & - & - & [16] \\
\hline & & $100-200$ & - & - & [8] \\
\hline & & $20-60$ & - & - & [17] \\
\hline & $13.1-98.8$ & - & - & - & [10] \\
\hline & - & 62.7 & - & - & [18] \\
\hline & $49.3^{1}$ & - & - & - & [18] \\
\hline & 74 & - & - & - & [18] \\
\hline & 261 & - & - & - & [19] \\
\hline & - & 5-90 & $50-100$ & $150-240$ & [20] \\
\hline & - & 66.7-156.5 & - & - & [15] \\
\hline & 114 & - & - & - & [21] \\
\hline \multirow{6}{*}{$\begin{array}{c}\text { TOC } \\
(\mathrm{g} \mathrm{C} / \mathrm{L})\end{array}$} & - & $6-20$ & - & - & [17] \\
\hline & $1.6-23.6$ & - & - & - & [10] \\
\hline & 92 & - & - & - & [19] \\
\hline & - & 7.6 & - & - & [18] \\
\hline & - & $1-1.6$ & - & - & [12] \\
\hline & - & $2-3$ & $24-60$ & $10-24$ & [20] \\
\hline \multirow{3}{*}{$\begin{array}{c}\mathrm{BOD}_{5} \\
\left(\mathrm{mg} \mathrm{O}_{2} / \mathrm{L}\right)\end{array}$} & - & $5000-10,000$ & - & - & [17] \\
\hline & - & 18,100 & - & - & [18] \\
\hline & $20,100^{1}$ & - & - & - & [18] \\
\hline \multirow{12}{*}{$\begin{array}{c}\text { Sulfides } \\
(\mathrm{mg} / \mathrm{L})\end{array}$} & - & $5000-20,000$ & - & - & [7] \\
\hline & \multirow[t]{2}{*}{-} & 80-90 & - & - & [8] \\
\hline & & 34,500 & - & - & [17] \\
\hline & $6500-22,500$ & - & - & - & [10] \\
\hline & - & $5100-7700$ & - & - & [7] \\
\hline & - & 17,800 & - & - & [18] \\
\hline & 8040 & - & - & - & [18] \\
\hline & - & $15,200-17,600$ & - & - & [12] \\
\hline & \multirow[t]{3}{*}{-} & $2000-52,000$ & $0-63$ & $<1$ & [20] \\
\hline & & - & $0-1$ & 0.1 & [14] \\
\hline & & $30,600-66,800$ & - & - & [15] \\
\hline & 24,000 & - & - & - & [21] \\
\hline \multirow{9}{*}{$\begin{array}{l}\text { Sulfides } \\
(\% w / w)\end{array}$} & - & $1-4$ & - & - & [17] \\
\hline & - & $0.5-4$ & $0-1$ & $0-0.1$ & [11] \\
\hline & 1.4 & - & - & - & [19] \\
\hline & - & $0.5-4$ & $0-4$ & $0-0.1$ & [4] \\
\hline & - & $0.5-4$ & - & - & [14] \\
\hline & - & $0-5$ & - & - & [7] \\
\hline & - & $2-300$ & - & - & [8] \\
\hline & - & $0-2000$ & - & - & [17] \\
\hline & $1.6-20$ & - & - & - & [10] \\
\hline \multirow{5}{*}{$\begin{array}{c}\text { Phenols } \\
(\mathrm{mg} / \mathrm{L})\end{array}$} & $1990^{1}$ & - & - & - & [18] \\
\hline & 6110 & - & - & - & [18] \\
\hline & - & $1.8-33.8$ & - & - & [12] \\
\hline & 540 & - & - & - & [21] \\
\hline & - & $0-30,000$ & - & - & [8] \\
\hline \multirow{4}{*}{$\begin{array}{c}\text { Mercaptans } \\
\quad(\mathrm{mg} / \mathrm{L}) \\
(\% w / w)^{\mathrm{a}}\end{array}$} & - & $0.1-4^{\mathrm{a}}$ & - & - & [17] \\
\hline & - & 9800 & - & - & [18] \\
\hline & 1800 & - & - & - & [18] \\
\hline & - & $0-30,000$ & $0-5400$ & $<30$ & [20] \\
\hline
\end{tabular}


Table 1. Cont.

\begin{tabular}{|c|c|c|c|c|c|}
\hline Parameters & SMC & Sulfidic & Cresylic & Naphtenic & Reference \\
\hline \multirow{3}{*}{ Benzene (mg/L) } & - & $47-780$ & - & - & [7] \\
\hline & - & $7.8-63.1$ & - & - & [12] \\
\hline & - & 600 & - & - & [15] \\
\hline \multirow{2}{*}{$\begin{array}{l}\text { Toluene } \\
(\mathrm{mg} / \mathrm{L})\end{array}$} & - & $0.2-7.8$ & - & - & [12] \\
\hline & - & 360 & - & - & [15] \\
\hline \multirow{3}{*}{$\begin{array}{l}\text { Cresylic acids } \\
\quad(\% w / w)\end{array}$} & - & - & $10-25$ & $0-3$ & [11] \\
\hline & - & $0-4$ & $2-25$ & $0-3$ & [4] \\
\hline & - & - & $2-25$ & $0-3$ & [14] \\
\hline \multirow{4}{*}{$\begin{array}{c}\text { Napthenic } \\
\text { acids } \\
(\% \mathrm{w} / \mathrm{w}) \\
(\mathrm{mg} / \mathrm{L})^{\mathrm{b}}\end{array}$} & - & - & - & $2-15$ & [11] \\
\hline & $19,700^{1, b}$ & - & - & - & [18] \\
\hline & - & - & - & $2-15$ & [4] \\
\hline & - & - & - & $2-15$ & [14] \\
\hline \multirow{7}{*}{$\begin{array}{l}\mathrm{NaOH} \\
(\% w / w)\end{array}$} & - & $4-5$ & - & - & [8] \\
\hline & - & 7.5 & - & - & [17] \\
\hline & $2-2.9$ & - & - & - & [10] \\
\hline & - & 11.1 & - & - & [3] \\
\hline & - & $2-10$ & $10-15$ & $1-4$ & [11] \\
\hline & - & $2-10$ & $1-15$ & $1-4$ & [4] \\
\hline & - & $2-10$ & $1-15$ & $1-4$ & [14] \\
\hline \multirow{4}{*}{$\begin{array}{l}\text { Carbonates } \\
(\% w / w)\end{array}$} & $2-2.9$ & - & - & - & [10] \\
\hline & - & $0-4$ & $0-0.5$ & - & [11] \\
\hline & - & - & $0-0.5$ & - & [4] \\
\hline & - & $0-4$ & $0-0.5$ & - & [14] \\
\hline
\end{tabular}

Often plants do not have the facilities to segregate the soda solutions used in these three types of classifications. Therefore, a spent mixed caustic (SMC) is usually produced. The latter is considered the fourth type of depleted or spent soda.

Processes of fuel gas, liquefied petroleum gas, and gasoline treatment generate sulfidic soda [13]. This depleted soda has a high concentration of sulfide and also a terrible smell. This type of waste can not only be treated but could also be a reactant for the cellulose pulping process. Nevertheless, the cost of transport generally discards this possibility [13].

The washing of the diesel and the fractions of jet fuels generate the exhausted naphthenic soda. It contains very few sulfides, being mainly naphthenic acids. Naphthenes generally do not impart unpleasant odors or toxicity to the caustic sodas, being partially soluble in sodas by increasing the total organic carbon considerably in SC. Naphtenes is a general term used for cyclic alkanes or non-aromatic hydrocarbons called cycloalkanes. Refinery naphthenes typically include cyclopentanes and cyclohexanes as compounds of this group. This type of waste can also be sold if it is kept insufficiently in pure form. However, processing at the same plant is most often the best option.

The exhausted cresylated soda (often called phenolic) is generated from the washing of gasoline fractions and is composed mainly of aromatic, acid oils, cresols, and other organic acids. Cresylates are a form of phenols containing a methyl group $\left(\mathrm{CH}_{3}\right)$, often called phenolics as a family or group of compounds. In their three forms, ortho, meta, and para cresol, they are not as toxic as phenols. However, the cresylates have relatively high concentrations, between $1 \%$ and $35 \%$. Cresylates or cresylic acids, often referred to as acid oils, are solubilized at high $\mathrm{pH}$, but readily separated at low $\mathrm{pH}$. It is not a question of eliminating these compounds from petroleum since they increase the amount of octane in the final fuel; however, these are present in different concentrations in the depleted sodas. The number of phenols in spent soda is the factor to consider it as a reagent for the production of phenolic compounds. Otherwise, the low amount of oily acids drastically increases the costs of transportation and its treatment in the plant is the best option. 
Due to the high content of organic matter, in addition to sulfur compounds, phenols, and mercaptans, the depleted sodas are a liquid residue tough to treat $[2,17]$, with a series of related problems with their treatment of depleted among those highlights [2]:

- Strong odors of sulfides and mercaptans: the odor traces of these compounds are in the order of parts per billion. As is known, these compounds are highly toxic even at minimal concentrations.

- High phenol concentrations: phenol is a highly inhibiting compound of biological activity. Deficient concentrations of phenol have been shown to inhibit the biological removal of organic matter.

- High concentrations of bio-refractory material: the presence of cresylic and naphthenic acids, which are difficult to biodegrade, is another problem associated with SC. Naphthenic acids facilitate foaming formation.

Shailja Singh and Shikha [22] mentioned the primary pollutants found in the effluent from various processes in refineries. The liquid effluents generated in the oil refineries differ from one industrial plant to another due to the variation in the configuration of the plant and in particular, to the type of petroleum processed. For example, ammonia and hydrogen sulfide are the main substances present in the wastewater from the isomerization process; meanwhile, the alkylation produces hydrofluoric acid. Other processes in this industry such as fluid catalytic cracking, crude desalting, catalytic hydrocracking, coking, distillation, catalytic hydrotreating, lubricating oil manufacture, sulfur removal, catalytic reforming, and thermal cracking are summarized in the same publication.

In general, liquid petrochemical residues contain significant concentrations of suspended solids (SS), chemical oxygen demand (COD), biochemical oxygen demand (BOD), oils and fats, sulfides, ammonium, phenols, hydrocarbons, benzene, toluene, ethylbenzene, xylene, polycyclic aromatic hydrocarbons, and heavy metals [23-26].

In order to avoid or reduce the environmental problems caused by SC, a series of processes have been proposed that help neutralize sodas and allow their subsequent biological treatment.

\section{Treatment Methods of SC}

\subsection{Initial Considerations}

In general terms, the treatment of spent sodas is carried out in two types of processes in series; the first one considers the removal of sulfides, phenols, and other compounds that can inhibit the biological processes. These are later applied in order to remove the organic matter present in this residue. The spent sodas cannot be directly biotreated for different reasons:

- The presence of phenols inhibits, at a specific concentration, the healthy metabolism of the microorganisms that operate in the biological process.

- Spent sodas contain some low biodegradable compounds, such as naphthenic acids.

- The presence of naphthenic acids may result in operational issues in aerobic processes through foam formation.

- The high COD concentration in SC makes impossible their direct treatment.

- They have a high $\mathrm{pH}$, which is not adequate for the development of microorganisms.

\subsection{Wet Air Oxidation (WAO)}

In practice, this is the most widely used chemical treatment applied to spent sodas. This process has been executed on several occasions as a pilot [27] at a plant [21,28-32] and laboratory level [33,34], in addition to the diverse industrial plants [35] that have implemented the WAO system. It is basically the oxidation of the soluble and suspended compounds that are present in this residue using oxygen or air as an oxidant [21]. The oxidation is carried out at very high temperatures and pressures, which depend on the strength of the material to be oxidized in the process and the quality required from the final effluent. 
In the WAO process, several chemical reactions take place, such as:

$$
\begin{gathered}
\text { Organics }+\mathrm{O}_{2} \rightarrow \mathrm{CO}_{2}+\mathrm{H}_{2} \mathrm{O}+\mathrm{RCOOH} \\
\text { Sulphur species }+\mathrm{O}_{2} \rightarrow \mathrm{SO}_{4}^{2-} \\
\text { Organochlorides }+\mathrm{O}_{2} \rightarrow \mathrm{Cl}^{-}+\mathrm{CO}_{2}+\mathrm{RCOOH} \\
\text { Organic nitrogen }+\mathrm{O}_{2} \rightarrow \mathrm{NH}_{3}+\mathrm{CO}_{2}+\mathrm{RCOOH} \\
\text { Phosphorus }+\mathrm{O}_{2} \rightarrow \mathrm{PO}_{4}^{3-}
\end{gathered}
$$

Three ranges divide the operational conditions: low, medium, and high-temperature systems [36]. Oxidation takes place at temperatures of $200^{\circ} \mathrm{C}$ and 27.5 bars in low-temperature systems. This system partially oxidizes sulfides into sulfates and thiosulfates [37]. In medium temperature systems, oxidation takes place in the range of $200{ }^{\circ} \mathrm{C}$ and 27.5 bars to $260^{\circ} \mathrm{C}$ and 86 bars. The ideal supply for this system is naphthenic caustics sodas. Sulfides react to sulfates, and the mercaptans are also destroyed [38]. The high-temperature systems oxidize the cresylic caustics at a range from $240{ }^{\circ} \mathrm{C}$ and 55 bars to 260 ${ }^{\circ} \mathrm{C}$ and 85 bars. Complete oxidation of sulfides, mercaptans, and other organic compounds can be carried out, such as cresylic acids [39]. The typical industrial WAO systems can work with spent sodas flows between 1 and $50 \mathrm{~m}^{3} / \mathrm{h}$ and with a COD between 10,000 and 100,000 mg/L. However, for COD levels above $50,000 \mathrm{mg} / \mathrm{L}$, dilutions with water or fresh caustic solution are required. Diluted caustic solutions help to reach different goals, among them, avoiding diluted salts concentrations below the solubility levels in order to prevent incrustations. The other reason is to guarantee that alkalinity is not consumed by oxidation when acid effluents could damage the construction materials of the system. Finally, the addition of the caustic solution can help the oxidation of contaminants according to the reactions that are described below [36].

Sulfide.

$$
\begin{gathered}
\mathrm{NaSH}+2 \mathrm{O}_{2}+\mathrm{NaOH} \rightarrow \mathrm{Na}_{2} \mathrm{SO}_{4}+\mathrm{H}_{2} \mathrm{O} \\
\mathrm{NaSH}+\mathrm{O}_{2} \rightarrow \frac{1}{2} \mathrm{Na}_{2} \mathrm{~S}_{2} \mathrm{O}_{3}+\frac{1}{2} \mathrm{H}_{2} \mathrm{O}
\end{gathered}
$$

Thiosulfate.

$$
\mathrm{Na}_{2} \mathrm{~S}_{2} \mathrm{O}_{3}+2 \mathrm{O}_{2}+\mathrm{NaOH} \rightarrow 2 \mathrm{Na}_{2} \mathrm{SO}_{4}+\mathrm{H}_{2} \mathrm{O}
$$

Mercaptan.

$$
\mathrm{NaSR}+\frac{3}{2} \mathrm{O}_{2} \rightarrow \mathrm{RSO}_{3}-\mathrm{Na}
$$

Cresylic acid.

$$
\begin{gathered}
\mathrm{C}_{6} \mathrm{H}_{5} \mathrm{O}-\mathrm{Na}+7 \mathrm{O}_{2}+11 \mathrm{NaOH} \rightarrow 6 \mathrm{Na}_{2} \mathrm{CO}_{3}+8 \mathrm{H}_{2} \mathrm{O} \\
\mathrm{C}_{6} \mathrm{H}_{5} \mathrm{O}-\mathrm{Na}+5 \mathrm{O}_{2}+8 \mathrm{NaOH} \rightarrow 4 \mathrm{Na}_{2} \mathrm{CO}_{3}+\mathrm{CH}_{3} \mathrm{COO}-\mathrm{Na}+8 \mathrm{H}_{2} \mathrm{O}
\end{gathered}
$$

Naphthenic acid.

$$
\begin{gathered}
\mathrm{Na}-\mathrm{C}_{12} \mathrm{H}_{22} \mathrm{O}_{2}+\frac{67}{7} \mathrm{O}_{2}+23 \mathrm{NaOH} \rightarrow 2 \mathrm{Na}_{2} \mathrm{CO}_{3}+\frac{45}{2} \mathrm{H}_{2} \mathrm{O} \\
\mathrm{Na}-\mathrm{C}_{12} \mathrm{H}_{22} \mathrm{O}_{2}+\frac{59}{4} \mathrm{O}_{2}+20 \mathrm{NaOH} \rightarrow 10 \mathrm{Na}_{2} \mathrm{CO}_{3}+\mathrm{CH}_{3} \mathrm{COO}-\mathrm{Na}+\frac{39}{2} \mathrm{H}_{2} \mathrm{O}
\end{gathered}
$$

The WAO process can treat liquid currents containing cyanide, several heterocyclic compounds, industrial sludge, and spent coal from adsorption processes [40]. Several industrial residues apply this process, such as paper manufacture, textile sludge, among others. Figure 1 shows an outline of a typical WAO process. 


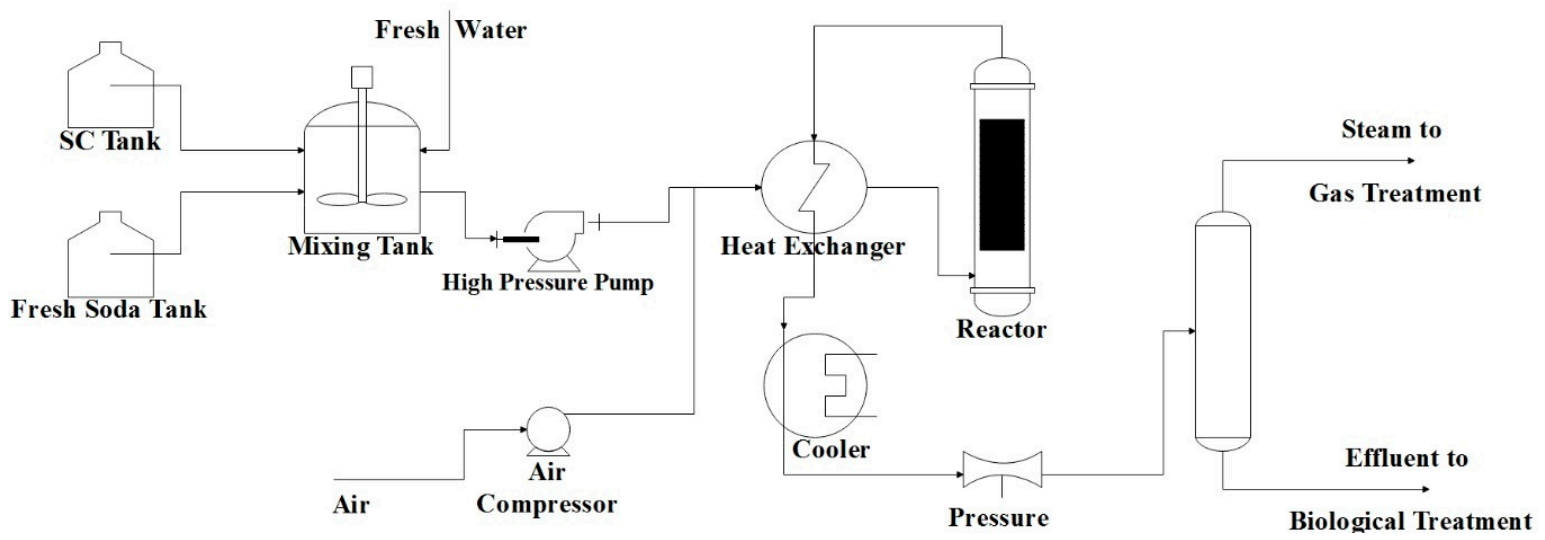

Figure 1. Typical outline of a wet air oxidation (WAO) system.

As can be seen in Figure 1, fresh soda or freshwater dilute the spent soda. The dilution ratio depends on the strength of the spent soda. Then, the diluted spent soda is pumped at $27.5-85$ bars through a high-pressure pump. The addition of compressed air to the diluted spent soda is required in order to supply the needed oxygen for the oxidation reaction. A heat exchanger preheated the mixture at $200-260^{\circ} \mathrm{C}$. The reactor must operate for a sufficient residence time that allows high oxidation of the organic matter contained in the spent sodas (COD disposal). Since the reaction is exothermic, the reactor's effluent has a high temperature, so it can be used to preheat the diluted spent sodas before entering the reactor [21]. Subsequently, the effluent coming out of the heat exchanger is cooled and depressurized before being sent to a gas-liquid separator. Then, the separated liquid goes to biological treatment. The effluent gas has $5 \%-21 \%$ of oxygen and some volatile organic compounds. In Table 2, the values of a sample of the operational conditions of a WAO system from the Oil Refinery of Manguinhos, S. A. in Rio de Janeiro, Brazil, are presented.

Table 2. Operational conditions of the WAO system in Manguinhos, Brazil [21].

\begin{tabular}{ccc}
\hline Parameters & Supply & Effluent \\
\hline Residence time $(\mathrm{h})$ & - & 1 \\
Oxidation temperature $(\mathrm{K})$ & - & 533 \\
COD $(\mathrm{g} / \mathrm{L})$ & 114 & $\approx 23$ \\
Sulfides $(\mathrm{g} / \mathrm{L})$ & $\approx 24$ & $<0.001$ \\
Total phenols $(\mathrm{g} / \mathrm{L})$ & $\approx 0.45$ & $<0.002$ \\
\hline
\end{tabular}

As can be observed, despite obtaining a removal percentage of $80 \%$ of COD, measured from organic matter, it is still very high. This concentration is required to be reduced until reaching the possible values to discharge it into a receiving current or another place for its final disposal. It could be carried out through a biological process that can be done in this case, provided the low levels of sulfides and phenols in the WAO effluent since the two chemical species were reduced in the process by almost $100 \%$. Additionally, most of the remaining COD in the treated effluent comes from aliphatic acids of low molecular weight, which can be biologically oxidized [37]. The oxidation pressure is directly related to the oxidation temperature. The oxidation pressure is responsible for keeping the reaction in the liquid phase. In this way, as the pressure increases, the oxidation pressure rises to keep the reaction in the liquid phase. The WAO processes typically operate with hydraulic residence times of 45-120 $\mathrm{min}$, the oxidation degree that takes place within the reactor affecting this parameter. Each WAO system uses different hydraulic residence times to reach the degree of COD reduction required. The selection of the construction material is critical in the WAO system, considering that the operation takes place at a high temperature and pressure. Thus, the materials used must be appropriate for these conditions. The WAO system presents some disadvantages and difficulties, among which the initial investment cost stands out. This cost depends mainly on the operating conditions, which, at the same 
time, are related to the strength of the residue to be treated. As this strength increases, more severe operating conditions are required, which increases the cost of the plant.

Tests and research are still carried out in order to improve this system, as well as combining this process with others. A way of reducing the severe operating conditions is the use of solid catalysts in the WAO to accelerate the reactions, and there are reports of cases where catalysts have been used in this process [8,41]. This innovative technique is referred to as catalytic wet air oxidation (CWAO). In recent years it has been studied in order to increase the efficiency to treat pollutants in industrial effluents [42]. The studies have been developed to remove individual toxic substances and to expose the best selection of metal catalyst-based support at lab scale. In general, the catalytic activity of transition metal such as Vanadium, Ferrum, Nickel, Copper and others have been chosen as the most common option.

Otherwise, researchers are still looking for better conditions of the process to treat most pollutants in spent caustic using this technology.

Nunez et al. [43] added silver to $\mathrm{Al}_{2} \mathrm{O}_{3}-\mathrm{ZrO}_{2}$ mixed oxide to reduce p-cresol at $160{ }^{\circ} \mathrm{C}$ and $15 \mathrm{bar}$ of $\mathrm{O}_{2}$ pressure, showing faster oxidation associated with more selectivity of this metal compared to the test without it. Additionally, it reported that the highest concentration $(20 \%)$ of $\mathrm{ZrO}_{2}$ in the catalyst removed $50 \%$ and $96 \%$ for TOC and p-cresol, respectively.

Jagushte and Mahajani [34] studied the effect of the heterogeneous copper catalyst in the kinetics of Equation (12) mentioned above at the lab-scale. As a result, the catalyst reduced the temperature and time process to $30^{\circ} \mathrm{C}$ from $150{ }^{\circ} \mathrm{C}$ and $4 \mathrm{~min}$ from $12 \mathrm{~min}$, respectively, in a conversion of $99 \%$ of the pollutant in alkaline conditions. It is remarkable to say that the batch experiments were carried out at low temperatures and $0.69 \mathrm{MPa}$ of oxygen partial pressure, showing first and 0.5 kinetic order concerning thiosulfate and oxygen, respectively. Additionally, this study explained a strategy to treat spent caustic under its results associated with the enhanced effect of phenols in the oxidation of thiosulfate.

A similar study was reported by Zermeño-Montante et al. [44]. In this case, copper catalyst in a silica support material achieved the complete sulfide oxidation at $70{ }^{\circ} \mathrm{C}$ in $20 \mathrm{~min}$. It showed better results than a similar experiment with Vanadium/Clinoptilolite just for $6 \mathrm{~min}$ latter. Both cases enhanced the WAO process for this pollutant. This report explained some of its results from Jagushte and Mahajani [34],

Recently, Barge and Vaidya [45] experimented with ferrous sulfate to eliminate sodium sulfide. That study innovated using a cheap and abundant catalyst, destroying $94 \%$ of COD at $100{ }^{\circ} \mathrm{C}$ and $0.69 \mathrm{MPa}$ of oxygen partial pressure within $1 \mathrm{~h}$. It is remarkable to say those authors exposed the Langmuir-Hinshelwood as the kinetic model to oxidize the reactant. These same authors, Barge and Vaidya [46] used Graphene oxide (GO) and Ruthenium ( $\mathrm{Ru}$ ) as a catalyst in WAO for the treatment of the cresylic spent caustic, obtaining the best results at $175{ }^{\circ} \mathrm{C}$ and $0.60 \mathrm{MPa}$ of $\mathrm{O}_{2}$ pressure, with removals of $54.9 \%, 48.9 \%$, and $61.2 \%$ as TOC, for 0 -cresol, m-cresol, and p-cresol, respectively, in the typical WAO. Meanwhile, when the Ru/GO catalyst was used for the same operating conditions, the removals obtained were $66.4 \%, 53.4 \%$, and $73.9 \%$, as TOC, for 0 -cresol, $m$-cresol, and $p$-cresol, respectively.

\subsection{Acid Neutralization}

In this type of process, alkaline caustic solution traps the acid components released from acidified spent sodas [36]. This action results in sulfides and mercaptans being released as acid gases, and naphthenic acids come to form some oil layer. One of the most significant differences between acid neutralization and the WAO process is that the acid components of spent sodas are removed but not destroyed, for example, phenols. In some cases, this entails the requirement of additional treatments for the acidification effluents, for example, gas ignition or methods for sulfur recovery. In other cases, this allows for any component present in spent sodas to be captured and reused.

As phenols are highly soluble in water, they are complicated to acidify. However, acidification eliminates the trend of the formation of foam, similar to the one obtained in the WAO process at high 
temperatures. The cause of this is mainly the fact that the naphthenic compounds that tend to form foam move to an insoluble phase and, even though they are not eliminated, they reduce their trend to form foam. Additionally, some alkaline compounds that could form foam are acidified, reducing this trend.

In some cases, acidification as a pretreatment for oxidation processes has been studied. Sheu and Weng [47] treated the spent sodas from olefin plants containing a considerable amount of $\mathrm{H}_{2} \mathrm{~S}$ and some mercaptans, phenols, and crude oils undergo a process of acid neutralization before a process with Fenton reagent. Using sulfuric acid with a $\mathrm{pH}$ of up to 5 , and $70{ }^{\circ} \mathrm{C}$, a little more than $90 \%$ of the dissolved $\mathrm{H}_{2} \mathrm{~S}$ changes to the gas phase. From this $\mathrm{pH}$, the conversion to dissolved sulfide $\left(\mathrm{S}^{2-}\right)$ is minimal [48]. These authors were the first to report this pretreatment process.

Nuñez et al. [49] showed a reduction of $71 \%$ and $82 \%$ of COD in two batch experiments using this procedure, under conditions of $\mathrm{pH}$ below 4 . In this context, only the sulfide content was reduced by $\mathrm{pH}$ reduction, the phenol concentration not being affected. The removal percentages were lower, considering the analysis made by Sheu and Weng [47] and it was attributed to the use of synthetic and real samples used. The last type has other substances that could inhibit the $\mathrm{pH}$ reduction to oxidize the reactants.

In summary, acid neutralization or acidification reduces most of the COD and the trend to form foam removing the naphthenic acids. Sulfuric acid is the chemical agent used in most cases in these processes, due to its strength and lower price in comparison with other acids [50].

\subsection{Advanced Oxidation Process (AOP)}

These processes are defined as the processes that involve the formation of radical hydroxyls $(\mathrm{OH})$ that oxidize both organic and inorganic contaminants present in water and wastewater [51]. These radicals are the second most potent oxidants after fluorides [52]. Unlike the physical process such as adsorption, filtration, and air stripping, the AOPs can destroy the contaminants rather than transferring them from one medium into another [53]. The AOPs can be used to treat wastewater with high COD and low biodegradability [54]. With these processes, complete oxidation of residues can be reached, converting contaminants into water, $\mathrm{CO}_{2}$, and innocuous inorganic products. However, it is expensive and impractical to use these processes for the complete mineralization of compounds since there are intermediate products that are resistant to chemical oxidation. A practical solution is to use these processes as a pretreatment for biological treatments. The partial mineralization produced by the AOPs generates intermediates with higher biodegradability and lower toxicity, which makes them available for biological oxidation. It is very important to determine the quality of the residue before selecting any AOP process, since this factor will affect the efficiency of the process, for example, residues with high alkalinity have an excess of carbonate and bicarbonate compounds, which may interfere with the oxidation reactions of hydroxyl radicals. These radicals react with those compounds forming weaker radicals resulting in lower efficiencies of the minor oxidation processes [55]. This issue can be solved by reducing the alkalinity to make sure there is no excess of these compounds in the residues, which can be achieved in a relatively simple way by lowering the $\mathrm{pH}$. Nitrates and nitrites can also affect the efficiency of the AOP processes, which use UV light to generate hydroxyl radicals. These compounds can absorb UV light and, thus, reduce the generation rate of free $\mathrm{OH}$ radicals. The turbidity has the same effect over the efficiency of the AOP processes as nitrates and nitrites. Turbidity reduces the production of hydroxyl radicals, since it acts as a barrier against UV light, which cannot penetrate through the residue to be treated.

The AOP reaction systems consist of a catalyst and an oxidant. The catalyst task is to form hydroxyl radicals from oxidants. There are several means to form these radicals, which can be photochemical, photo-catalyzed, ultrasonic, and chemical oxidations.

The photochemical processes include UV radiation. Some studies mention the use of this technology individually. Gurol and Vatistas [56] irradiated by UV a mixture of various phenolic compounds, using 16 low-pressure mercury lamps, each of which emitted 2.2 Watts of radiation at 
$254 \mathrm{~nm}$. The results showed a faster initial rate remotion of phenol at pH 2.5 than $\mathrm{p}$-cresol and xylenol at the same condition. The duration of the experiments was $100 \mathrm{~min}$, starting in $50 \mathrm{mg} / \mathrm{L}$ of the three substances and achieving remotions in the range of $20 \%-30 \%$. Neutral and basic ( $\mathrm{pH} 9$ ) conditions did not exhibit significant changes in the initial rate remotion, observing the same removal efficiency for those compounds at the same time. The authors concluded that the understanding of the reaction mechanism at low-pH irradiation requires further research.

Spent caustic from the ethene plant were irradiated with UV by Yu et al. [57]. The results showed low-efficiency COD removal (under 10\%) in $180 \mathrm{~min}$ using an ultraviolet light source of $254 \mathrm{~nm}$ wavelength. The high content of several persistent pollutants in spent caustic is not affected when this technology is used by itself. That is why the UV radiation has not attracted industrial applications and also lab-scale studies, and this is the evidence of a few reports about it.

Other photochemical technologies like ozone systems $\left(\mathrm{UV} / \mathrm{O}_{3}\right)$ and $\left(\mathrm{UV} / \mathrm{O}_{2}\right)$ systems have been reported. Photo-catalysis includes photo-Fenton, while chemical oxidation includes $\mathrm{O}_{3} / \mathrm{H}_{2} \mathrm{O}_{2}$ and $\mathrm{H}_{2} \mathrm{O}_{2} / \mathrm{Fe}^{3+}$.

\subsubsection{Ozone and UV Radiation $\left(\mathrm{O}_{3} / \mathrm{UV}\right)$}

Ozone in water is an unstable compound, dissociating in alkaline water and forming free radicals according to the following mechanism [58]:

$$
\begin{gathered}
\mathrm{O}_{3}+\mathrm{OH}^{-} \rightarrow \mathrm{O}_{3}^{-}+\mathrm{OH}^{-} \\
\mathrm{O}_{3}^{-} \rightarrow \mathrm{O}_{2}+\mathrm{O}^{-} \\
\mathrm{O}^{-}+\mathrm{H}^{+} \rightarrow \mathrm{OH}
\end{gathered}
$$

The $\mathrm{pH}$ increase promotes the formation of hydroxyl radicals. The main disadvantage of using only ozone is that the number of radicals produced is low, so in order to increase the efficiency of the ozone, it is combined with other physical methods, such as UV rays, ultrasound or chemicals, like hydrogen peroxide and Fenton reagent.

The photolysis of $\mathrm{O}_{3}$ starts the advanced oxidation processes with $\mathrm{O}_{3}$ and $\mathrm{UV}$ according to the following reaction:

$$
\mathrm{O}_{3}+\mathrm{H}_{2} \mathrm{O} \stackrel{\mathrm{hv}}{\rightarrow} \mathrm{H}_{2} \mathrm{O}_{2}+\mathrm{O}_{2}
$$

The hydrogen peroxide formed reacts then with the ozone to produce the free radical according to:

$$
\mathrm{O}_{3}+\mathrm{H}_{2} \mathrm{O}_{2} \rightarrow 2 \mathrm{OH} \cdot+3 \mathrm{O}_{2}
$$

Ozone photolysis occurs when UV radiation (wavelength of $254 \mathrm{~nm}$ ) is applied to ozone-saturated water [59]. According to Equations (21) and (22), in order to produce 1 mol of hydroxyl radical, the consumption of $1 \mathrm{~mol}$ of ozone and half a mol of hydrogen peroxide is required. In this system, contaminant degradation can occur due to the chemical oxidation of hydroxyl radical, the direct oxidation of ozone, as well as the photolysis caused by the UV.

Two essential parameters considered those systems: the UV dose and the ozone concentration. The UV dose required per ozone is responsible for the formation of radicals and it depends on the strength of the water to be treated. Other important parameters to be considered in order to guarantee efficient operations of these systems are the $\mathrm{pH}$ and the cleaning system of the radiation lamp [60]. The $\mathrm{pH}$ can influence the hydrogen peroxide generation. For a $\mathrm{pH}$ of less than 1.8, the photolysis requires $1 \mathrm{~mol}$ of ozone to react with $1 \mathrm{~mol}$ of hydrogen peroxide. However, as the $\mathrm{pH}$ increases, this ratio decreases. Cleaning the lamps is very important in order to avoid their siltation. The cleaning frequency depends on the concentration of the compounds that can produce siltation, such as iron, calcium, and magnesium. 
Gurol and Vatistas [56] also studied this technology. At lower $\mathrm{pH} 2.5$, selective removal of phenols, p-cresol, and xylenol were shown compared to neutral and alkaline conditions using ozone doses of $3.8 \mathrm{mg} / \mathrm{L}$. Otherwise, a direct relation between $\mathrm{pH}$ and pollutant removal was reported. These three substances were completely reduced at $100 \mathrm{~min}$ and $\mathrm{pH}$ 9. Therefore, this research exposed an additive effect of the O3/UV system compared to its use individually.

Results for spent caustic from the ethene plant also were reported by Yu et al. [57]. They showed COD removal and BOD/COD ratio improvement with the increase of ozone dosage in this technology. An optimum of $3.3 \mathrm{~g}$ of $\mathrm{COD}$ removal per gram of $\mathrm{O}_{3}$ at a low dosage $\left(0.6 \mathrm{~g} \mathrm{O}_{3} / \mathrm{L}\right)$ was found.

The advantages of these systems are the high removal that ozone and UV radiations produce since more free radicals are produced than with other AOP systems. The main disadvantage of this system is that ozone has to be disseminated through the liquid, which may be limited by the mass transfer in the medium. The low stability of ozone in water can result in a higher energy demand, which increases the capital and operational costs of the system. The last statement is part of the conclusions in the paper mentioned before.

\subsubsection{Hydrogen Peroxide and UV Radiation $\left(\mathrm{H}_{2} \mathrm{O}_{2} / \mathrm{UV}\right)$}

In this system, hydroxyl radicals are formed through two mechanisms: hydrogen peroxide photolysis and hydrogen peroxide decomposition [61]. The formation of hydroxyl radicals from hydrogen peroxide photolysis is shown in the following reaction:

$$
\mathrm{H}_{2} \mathrm{O}_{2} \stackrel{\text { hv }}{\rightarrow} 2 \mathrm{HO}
$$

The wavelength for this reaction is $250 \mathrm{~nm}$. This reaction depends on the $\mathrm{pH}$ and, as it increases, the number of hydroxyls also raises, and so does the number of hydroxyl radicals. The propagation reactions of hydrogen peroxide are the following:

$$
\begin{aligned}
\mathrm{H}_{2} \mathrm{O}_{2}+\mathrm{HO} \cdot & \rightarrow \mathrm{HO}_{2} \cdot+\mathrm{H}_{2} \mathrm{O} \\
\mathrm{H}_{2} \mathrm{O}_{2}+\mathrm{HO}_{2} \cdot & \rightarrow \mathrm{HO} \cdot+\mathrm{O}_{2}+\mathrm{H}_{2} \mathrm{O} \\
2 \mathrm{HO}_{2} \cdot & \rightarrow \mathrm{H}_{2} \mathrm{O}_{2}+\mathrm{O}_{2}
\end{aligned}
$$

Finally, the chain reaction finishes:

$$
2 \mathrm{HO} \cdot \rightarrow \mathrm{H}_{2} \mathrm{O}_{2}
$$

Hydrogen peroxide follows two paths: the path of radiation and the path of decomposition. However, the path of radiation is more efficient as more free radicals are formed, consuming fewer peroxides. It is vital to keep the amount of peroxide as low as possible since this is an expensive material. Some of the critical parameters of this system are the intensity of the UV lamp, the contact time within the reactor, the operating pressure and temperature, and the dose of hydrogen peroxide. The intensity of the lamp is necessary to form hydroxyl radicals and is, mainly, a residue strength function.

The main advantage of this AOP system is that it reaches a higher removal of contaminants than the $\mathrm{UV}$ or $\mathrm{H}_{2} \mathrm{O}_{2}$ systems individually. However, as previously mentioned, the presence of a certain degree of turbidity harms the efficiency of the process. The non-contaminant compounds present in the treated medium can also absorb UV, reducing the efficiency of the process.

The use of hydrogen peroxide and UV radiation to treat ethene spent caustic also has been reported by $\mathrm{Yu}$ et al. [57]. The experiments showed almost $70 \%$ of COD removal efficiency when the ratio of 0.8 by $\mathrm{H}_{2} \mathrm{O}_{2} / \mathrm{COD}$ was used. This article mentioned a direct relation of $\mathrm{H}_{2} \mathrm{O}_{2}$ dosage with removal efficiencies of $\mathrm{COD}$, but it reported the ratio amount mentioned before as the optimum condition. While the hydroxyl radicals from the photolysis of $\mathrm{H}_{2} \mathrm{O}_{2}$ reacts with COD, a higher amount of $\mathrm{H}_{2} \mathrm{O}_{2}$ 
inhibits this system. Additionally, it mentioned that the combination of $\mathrm{H}_{2} \mathrm{O}_{2}$ and UV showed better results than the use of these individual technologies.

In summary, this technology has not been widely studied and reported to treat spent caustic, even when it is cheaper than the $\mathrm{O}_{3} / \mathrm{UV}$ system when it was compared in textile effluent [62].

\subsubsection{Ozone with Hydrogen Peroxide}

The addition of $\mathrm{H}_{2} \mathrm{O}_{2}$ to the system improves the production rate of hydroxyl radicals, as shown in Section 3.4.1, according to Equation (22). This system is similar to the UV-hydrogen peroxide system. However, the residue characteristics, such as the turbidity, influence the ozone-hydrogen peroxide system less [62]. No information reported means that further research using this technology must be studied to treat spent caustic.

\subsubsection{Ozone, Hydrogen Peroxide and UV Radiation $\left(\mathrm{O}_{3} / \mathrm{H}_{2} \mathrm{O}_{2} / \mathrm{UV}\right)$}

This system uses two oxidants, $\mathrm{O}_{3}$ and $\mathrm{H}_{2} \mathrm{O}_{2}$, in order to increase the formation of hydroxyl radicals. At lab-scale $\mathrm{Yu}$ et al. [57] reported the optimum loaded of $\mathrm{H}_{2} \mathrm{O}_{2}$ and $\mathrm{O}_{3}$ as 0.8 and 0.6 $\mathrm{g} / \mathrm{L}$, respectively, to reach $76 \%$ COD removal in the treatment of spent caustic from the ethene plant. This research mentioned the improvement in the BOD/COD ratio from 0.22 to 0.52 when this technology is used, compared to the $\mathrm{H}_{2} \mathrm{O}_{2} / \mathrm{UV}$ system. Even though the removal of the contaminants is increased in the same way, the treatment costs also rise rapidly due to the use of two oxidants [62].

\subsubsection{Ozonation and Ultrasound}

Ultrasound is used to form hydroxyl radicals [63]. Ultrasound waves are transmitted and introduced into the wastewater in alternate cycles of compression and expansion. This process creates microbubbles when the amplitude of the expansion cycle is big enough to increase the molecular distance to a distance higher than the required to remain in the liquid phase. The following compression cycle makes the microbubbles collapse, producing extremely high temperatures and pressures, which causes the breakdown of molecular water producing hydroxyl radicals. Several factors influence the ultrasound systems, among which are the ultrasound frequency and the temperature and pressure of the dissolved gas. The intensity of the ultrasound is related to the formation rate of hydroxyl radicals. Higher ultrasound frequencies reduce the microbubbles' collapse time resulting in a very low possibility of recombination of hydroxyl radicals, which entails a higher generation rate of hydroxyl radicals.

Occasionally, ozone is used along with an ultrasound to promote the formation of hydroxyl radicals and improve the removal of contaminants [51].

The reaction produced between ozone and ultrasound in order to generate hydroxyl radicals is as follows:

$$
\begin{gathered}
\mathrm{H}_{2} \mathrm{O} \stackrel{\text { ultrasound }}{\rightarrow} \mathrm{H} \cdot+\mathrm{OH} \cdot \\
\mathrm{O}_{3} \stackrel{\text { ultrasound }}{\rightarrow} \mathrm{O}_{2}+\mathrm{O}\left({ }^{3} \mathrm{P}\right) \\
\mathrm{O}\left({ }^{3} \mathrm{P}\right)+\mathrm{H}_{2} \mathrm{O} \rightarrow 2 \mathrm{OH} \cdot \\
\mathrm{O}_{2}+\mathrm{H} \cdot \rightarrow \mathrm{HO}_{2} \cdot \\
\mathrm{O}_{3}+\mathrm{HO}_{2} \cdot \rightarrow 2 \mathrm{O}_{2}+\mathrm{OH} \cdot \\
\mathrm{O}_{3}+\mathrm{HO}_{2} \cdot \rightarrow 2 \mathrm{O}_{2}+\mathrm{OH} \cdot \\
\mathrm{OH} \cdot+\mathrm{OH} \cdot \rightarrow \mathrm{H}_{2} \mathrm{O}_{2} \\
\mathrm{HO}_{2} \cdot+\mathrm{OH} \cdot \rightarrow \mathrm{H}_{2} \mathrm{O}+\mathrm{O}_{2}
\end{gathered}
$$

The main advantage of this system is that the energy required to form the hydroxyl radicals is lower than the other AOPs, especially the ones that use UV, reducing the operational costs. The 
main disadvantage is that the amount of oxidant required, either ozone or hydrogen peroxide, is high, which raises the operational costs [63]. There is no information reported about this system, meaning that further research using this technology must be studied to treat spent caustic.

\subsubsection{Fenton Reagent}

The AOP system uses hydrogen peroxide as an oxidant agent and mixes it with a catalyst, which is ferrous ion [64]. The reaction of hydrogen peroxide and ferrous ion is called Fenton chemistry. Its practical application was carried out until the 60s [65], and it was used for the treatment of textile liquid residues, liquid effluents, pulp and paper liquid effluents, and acid waters of petroleum refineries [66].

The main advantages of this AOP system are its high efficiency and capacity to treat several contaminants. Some organics of low molecular weight, such as paraffin, chlorinated alkanes, and some short-chain carboxylic acids, are resistant to Fenton's oxidation.

The reactions involved in this system for the formation of hydroxyl radicals are the following:

$$
\mathrm{Fe}^{2+}+\mathrm{H}_{2} \mathrm{O}_{2} \rightarrow \mathrm{Fe}^{3+}+3 \mathrm{OH} \cdot+\mathrm{OH}^{-}
$$

This is the initial reaction of the Fenton reaction. The formation of hydroxyl radicals is developed through a complex chain reaction. Once the ferrous ion is formed, it can react with the hydrogen peroxide according to:

$$
\mathrm{Fe}^{3+}+\mathrm{H}_{2} \mathrm{O}_{2} \leftrightarrow \mathrm{Fe}-\mathrm{OOH}^{2+}+\mathrm{H}^{+}
$$

$\mathrm{Fe}-\mathrm{OOH}^{2+}$ is an intermediate that is decomposed to form $\mathrm{HO}_{2}$ radicals according to the following reaction:

$$
\mathrm{Fe}-\mathrm{OOH}^{2+} \rightarrow \mathrm{HO}_{2} \cdot+\mathrm{Fe}^{2+}
$$

$\mathrm{HO}_{2}$ can oxidize contaminants, however, its oxidation power is much lower than other radicals. Other chain reactions that occur in this system are the following:

$$
\begin{gathered}
\mathrm{Fe}^{2+}+\mathrm{HO}_{2} \cdot \mathrm{Fe}^{3+}+\mathrm{HO}^{2-}+\mathrm{OH}^{-} \\
\mathrm{Fe}^{2+}+\mathrm{HO}_{2} \cdot \rightarrow \mathrm{Fe}^{2+}+\mathrm{O}_{2}+\mathrm{H}^{+} \\
\mathrm{OH} \cdot+\mathrm{H}_{2} \mathrm{O}_{2} \rightarrow \mathrm{H}_{2} \mathrm{O}+\mathrm{HO}_{2} .
\end{gathered}
$$

Finally, the last step is carried out through the following reaction:

$$
\mathrm{OH} \cdot+\mathrm{Fe}^{2+} \rightarrow \mathrm{OH}^{-}+\mathrm{Fe}^{3+}
$$

The global reaction can thus be formulated as:

$$
2 \mathrm{Fe}^{2+}+\mathrm{H}_{2} \mathrm{O}_{2}+2 \mathrm{H}^{+} \rightarrow 2 \mathrm{Fe}^{3+}+2 \mathrm{H}_{2} \mathrm{O}
$$

As it can be observed, the Fenton reaction requires an acid medium for it to occur. Once the hydroxyl radicals are formed, the oxidation of contaminants takes place. If the oxidation is complete, the contaminants can decompose in water, $\mathrm{CO}_{2}$, and some innocuous inorganic salts [67].

The hydroxyl radicals can oxidize organic radicals $(\mathrm{RH})$ through the removal of the organic radical protons that form organic radicals, for example, according to:

$$
\mathrm{RH}+\mathrm{OH} \cdot \rightarrow \mathrm{H}_{2} \mathrm{O}+\mathrm{R} \cdot
$$

This reaction is a chain propagation reaction. Once the organic hydroxyls are formed, the subsequent oxidation can occur [68].

$$
\mathrm{R} \cdot+\mathrm{H}_{2} \mathrm{O}_{2} \rightarrow \mathrm{ROH}+\mathrm{OH} \cdot
$$




$$
\mathrm{R} \cdot+\mathrm{O}_{2} \rightarrow \mathrm{ROO} \cdot
$$

Organic radicals can follow other paths. They can be oxidized with ferrous ions, reduced with ferrous ions, or two radicals can be dimerized, as shown below:

Oxidation

$$
\mathrm{R} \cdot+\mathrm{Fe}^{3+} \rightarrow \mathrm{R}^{+}+\mathrm{Fe}^{2+}
$$

Reduction

$$
\mathrm{R} \cdot+\mathrm{Fe}^{2+} \rightarrow \mathrm{R}^{-}+\mathrm{Fe}^{3+}
$$

Dimerization

$$
2 R \cdot \rightarrow R-R
$$

In addition to the oxidation of the contaminants through the Fenton reagent, this method can show coagulation effects. Adjusting the $\mathrm{pH}$ in the 5-7 range, the precipitation of dissolved ferrous particles can be achieved. The precipitated ferrous particles are combined to form flocs that can contribute to the removal of the dissolved solids. As a result, in this system, it is possible to obtain the treatment of residues by chemical oxidation and coagulation [69]. The chemical oxidation prevails when the ratio of hydrogen peroxide:ferrous salts is above 2 . On the other hand, the coagulation effect prevails when this ratio is below 0.2. It is essential to select the appropriate ratio correctly in order to guarantee the destruction of the contaminants since the goal of this system is to destroy the contaminants and not just physically separate them.

Other essential parameters in the Fenton reaction that are to be assessed are $\mathrm{pH}$, temperature, ferrous salts concentration, and reaction time [70,71]. The typical values of $\mathrm{pH}$ are within the $3-5$ range. Regarding temperature, it is necessary to know that this reaction is exothermic.

Ferrous salts (ferrous sulfate) are responsible for the generation of hydroxyl radicals, which convert the ferrous ion to ferrous particles, known as coagulant agents. As the concentration of ferrous salts increases, the coagulation is incremented. The reaction time is crucial in order to guarantee a sufficient residence time that allows oxidation to be completed in the required degree. Once the Fenton reaction is completed, high strength contaminants are oxidized into organic acids of low molecular weight, which are easily treated in biological treatments.

The main advantage of this process is its capacity to treat residues with different flows and organic contents. Another advantage is the COD removal that can generally reach up to $95 \%$, which is higher than other AOP processes. The system also can destroy some pollutants such as sulfides and mercaptans. In contrast, the process has low capital costs and is relatively easy to install.

\subsection{Electrochemical Processes}

Recently, some methods based on electrochemistry have been studied for the treatment of different residues, including the liquid residues produced in the oil industry [72,73]. In these methods, electric power is produced from a global reaction of oxidation-reduction (a half-reaction of oxidation that occurs in the anode and another of reduction, which occurs in the cathode), as shown in Figure 2. The three operational parameters that are always present in these methods, regardless of the modality applied, are the current density used, the sulfide load applied to the system, and the time used in the process.

Electrocoagulation is a variant of the electrochemical process that has been studied for the treatment of liquid effluents [74,75]. In this method, a flocculating agent is generated in the anode, at a certain $\mathrm{pH}$, which allows removal of the sulfides, among other soluble materials, as in this case, since the hydroxyl ions produced in the cathode increase the $\mathrm{pH}$ in the medium and cause the precipitation of the sulfides [76]. Hariz et al. [17] obtained sulfides and organic matter removals over $80 \%$ in a simple electrocoagulation system, while operating with subsequent electrocoagulation, they reached removal efficiencies of over $95 \%$ for both contaminants, operating at $\mathrm{pH} 9$ and $21.2 \mathrm{~mA} / \mathrm{cm}^{2}$ with initial concentrations of $34,517 \mathrm{mg} / \mathrm{L}$ and COD of $72,450 \mathrm{mg} / \mathrm{L}$ for $30 \mathrm{~min}$. 


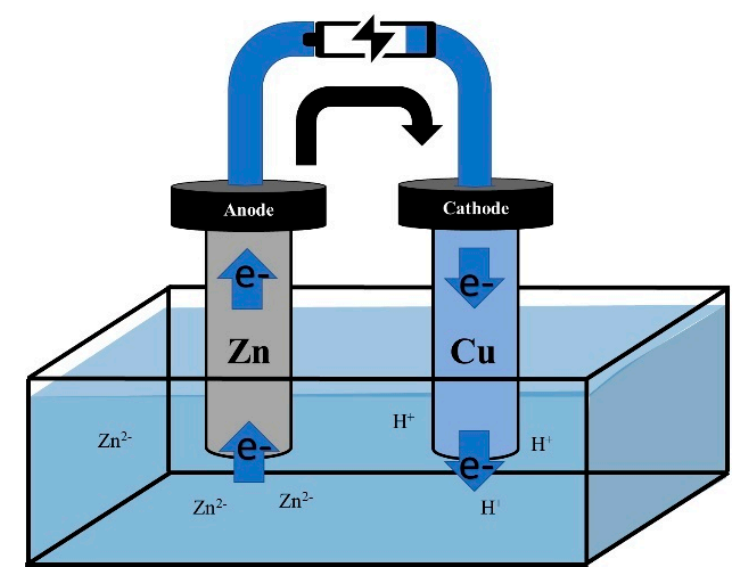

Figure 2. Chemical species of hydrogen sulfide in an aqueous medium according to $\mathrm{pH}$.

Other electrochemical methods studied for the SC treatment are based on electrodialysis (ED), which consists of extracting ionized substances dissolved in an aqueous dissolution through selective membranes of ion exchange [77]. Based on this principle, the electro-electro-dialysis (EED) has been developed, which combines water electrodialysis and ions transport through selective membranes of ions exchange [78]. A more advanced electrodialysis process is the so-called bipolar membrane electro-dialysis (BMED), where a bipolar membrane is used to separate the water in $\mathrm{H}^{+}$and $\mathrm{OH}^{-}$, producing caustic flows with acids [79]. This process adjusts the $\mathrm{pH}$ of a solution without adding acids or bases. In this case, the polarity of the electrodes is inverted periodically exchanging the outputs of the membrane accumulator of the freshwater produced and residual water. The ions are transferred in opposite directions through the membranes, which contributes to breaking the incrustations and washing and outside exiting of sludge and other deposits of the cells. In a research study, EED and BMED were applied for the regeneration of sodium hydroxide present in SSC [80]; and it was found that BMED was more efficient in terms of caustic soda recovery, consuming little more energy than in EED.

As it was described in Section 3.4.6, the system based on the Fenton reaction has been successfully applied for the removal of SSC. However, for this reaction to occur, it is necessary to add $\mathrm{H}_{2} \mathrm{O}_{2}$, in order to avoid this inconvenience. Hydrogen peroxide can be formed through an electrochemical process called electro-Fenton [81]. Davarnejad et al. [82] applied an electro-Fenton process to SSC. They assessed the effect of the operational parameters that influenced the removal of hydrogen sulfide: $\mathrm{pH}$, current density, reaction time, among others, finding that, in order to have optimal operating conditions, at $\mathrm{pH}$ of 2.87 a reaction time of $65.52 \mathrm{~min}$ and a current density of $55.47 \mathrm{~mA} / \mathrm{cm}^{2}$ was required. The removal percentages were $81 \%$ and $100 \%$ for COD and sulfides, respectively.

As shown in Section 3.4, the use of UV rays in the AOP contributed significantly to the formation of free radicals that react and oxidize the sulfides and organic matter present in SCC. This is why, in the electro-Fenton process, applying UV increases the formation of free radicals. In this sense, Esfahani et al. [7] reached COD removals of $97 \%$, operating at $4.5 \mathrm{pH}$ at $60^{\circ} \mathrm{C}$ for $80 \mathrm{~min}$ and a current density of $16.6 \mathrm{~mA} / \mathrm{cm}^{2}$.

Microbial fuel cell (MFC) is a process based on the fundamentals of electrochemistry, where the energy that contains the organic matter can be captured in the form of electricity from the work of microorganisms [83]. In this case, the movement of the electrons is produced through bacterial metabolism, where the electrons are transferred from a substrate to an electron acceptor at a higher redox potential, this means that while substrates are oxidized, the microorganisms produce protons and electrons, and their transfer to the cathode produces electricity [84,85]. Fazli et al. [86] operated an MFC with SSC at different retention times and suspended solids concentrations (SS), obtaining the higher efficiencies of COD and sulfides removal of $98 \%$ and $99 \%$, respectively, for 9 days of retention time. The optimal concentration of SS for the MFC process was of $1500 \mathrm{mg} / \mathrm{L}$, reducing COD and sulfides by $94.07 \%$ and $89.01 \%$, respectively. The higher voltage for the same retention time was $82.1 \mathrm{mV}$. 
The possibility to recover $\mathrm{NaOH}$ from an electrochemical process, in this case, electro-dialysis and electro-deionization, was proven by Keramati et al. [87].

\subsection{Biological Processes}

In general, the biological methods are environmentally more beneficial and more economical than the physic-chemical ones for most of the industrial processes, including residue treatment [87]. However, one of their limitations is that the microorganisms that operate in these processes can stand limited concentration levels of several substances, such as sulfides [88]. In order to overcome this limitation, several studies applied biological methods to SSC. De Graaf et al. [89] operated aerobic gas-lift reactors with retention times of 3.4-3.7 days with extremophile bacteria extracted from lake sediments with high levels of alkali to treat SC with $160-240 \mathrm{mM}$ of sulfide contents. However, this concentration was reduced when mixing SSC with sodium carbonate solution at $\mathrm{pH}$ 9.5. Complete removal was reached up to $27 \mathrm{mM} \mathrm{S/L}$-day through the conversion into sulfide by the halo-alkaline bacteria Thioalkalivibrio, also obtaining the removal of $93 \%$ of benzene. De Graff et al. [5] assessed a system in two aerobic stages, the first abiotic and the second with halo-alkaline bacteria inoculum, obtaining high removal rates of $33 \mathrm{mM} / \mathrm{L}$-day operating the first reactor with 2 days of retention time and the second one with 3.5 days. The affluent to the first reactor was a synthetic solution simulating diluted SSC.

The microorganisms work correctly at absolute $\mathrm{pH}$ values depending on the specific species to be treated. For example, it has been determined that one of the few reported microorganisms known for the elimination of sulfides of SSC is Thiobacillus denitrificans, which operates correctly around neutral $\mathrm{pH}$ [90]. Considering the high values of $\mathrm{pH}$ of SSC, the dilution of these residues is required so they can be biologically treated. The use of the Aspergillus sp. mushroom has also been assessed for the SSC treatment, previously diluted, obtaining COD removals, total diluted solids, and sulfites, after 10 days, of $16 \%, 10 \%$, and $55 \%$, respectively [91].

\subsection{Other Processes}

Ionic liquids (ILs), also called green solvents, have been described by several authors as ionic salts and their melting point is less than $100{ }^{\circ} \mathrm{C}$ [92]. Due to these characteristics, however, they have been recently determined as a substitution alternative to organic solvents for the extraction of phenols and several organic compounds in aqueous systems [93]. Two quaternary ammonium-based ILs were applied to SSC, reaching in both cases efficiencies of $99 \%$ for the removal of phenols and mercaptans [16].

The treatment with oxidant agents such as sodium hypochlorite and spent sulfochromic mixtures have been assessed at a laboratory scale [94]. The reactions involved in these processes are the following:

$$
\begin{gathered}
\mathrm{HS}^{-}+4 \mathrm{NaOCl} \rightarrow 4 \mathrm{NaCl}+\mathrm{SO}_{4}^{2-}+\mathrm{H}^{+} \\
29 \mathrm{H}^{+}+3 \mathrm{HS}^{-}+4 \mathrm{Cr}_{2} \mathrm{O}_{7}^{2-} \rightarrow 3 \mathrm{SO}_{4}^{2-}+8 \mathrm{Cr}^{3+}+16 \mathrm{H}_{2} \mathrm{O}
\end{gathered}
$$

With hypochlorite, no elemental sulfur was formed, reducing the COD by over $99 \%$. The oxidation of organic matter explains why the consumption of sodium hypochlorite was higher $(\approx 20 \%)$ than the stoichiometric amount required to oxidize all the $\mathrm{HS}^{-}$ions.

The sulfochromic mixture also annihilated $99 \%$ of the COD discoloring the spent sodas solution. The free acidity was dramatically reduced from 8 to $0.5 \mathrm{~mol} / \mathrm{L}$ ( $\approx 6 \%$ of the initial value).

In both cases, an effluent of those treatments without $\mathrm{SH}^{-}$was obtained. It had to be neutralized with sulfuric acid at $\mathrm{pH} 7$ before being ultimately arranged and, also, a residue with a high content of $\mathrm{Na}_{2} \mathrm{SO}_{4}$ remains.

The precipitation of insoluble sulfurs begins by obtaining precipitates of iron and manganese hydroxide precipitates, which can be obtained from the $\mathrm{NaOH}$ existent in the refinery according to the following reactions [94]:

$$
\mathrm{FeCl}_{3}+3 \mathrm{NaOH} \rightarrow \mathrm{Fe}(\mathrm{OH})_{3} \downarrow+3 \mathrm{NaCl}
$$




$$
\begin{gathered}
\mathrm{FeSO}_{4}+2 \mathrm{NaOH} \rightarrow \mathrm{Fe}(\mathrm{OH})_{2} \downarrow+3 \mathrm{Na}_{2} \mathrm{SO}_{4} \\
\mathrm{MnCl}_{2}+2 \mathrm{NaOH} \rightarrow \mathrm{Mn}(\mathrm{OH})_{2} \downarrow+2 \mathrm{NaCl}
\end{gathered}
$$

In this last case, some drops of $\mathrm{H}_{2} \mathrm{O}_{2}(30 \%)$ are added, and the $\mathrm{Mn}$ (II) oxidizes to $\mathrm{Mn}$ (IV) according to:

$$
\mathrm{Mn}(\mathrm{OH})_{2}+\mathrm{H}_{2} \mathrm{O}_{2} \rightarrow \mathrm{MnO}(\mathrm{OH})_{2} \downarrow+\mathrm{H}_{2} \mathrm{O}
$$

Thus, the reactions involved are:

$$
\begin{aligned}
& 2 \mathrm{Fe}(\mathrm{OH})_{3}+3 \mathrm{NaSH} \rightarrow 2 \mathrm{FeS} \downarrow+\mathrm{S} \downarrow+3 \mathrm{NaOH}+3 \mathrm{H}_{2} \mathrm{O} \\
& \mathrm{Fe}(\mathrm{OH})_{2}+\mathrm{NaSH} \rightarrow \mathrm{FeS} \downarrow+\mathrm{NaOH}+\mathrm{H}_{2} \mathrm{O} \\
& \mathrm{MnO}(\mathrm{OH})_{2}+\mathrm{NaSH} \rightarrow \mathrm{Mn}(\mathrm{OH})_{2}+\mathrm{S} \downarrow+\mathrm{NaOH} \\
& \mathrm{Mn}(\mathrm{OH})_{2}+\mathrm{NaSH} \rightarrow \mathrm{MnS} \downarrow+\mathrm{NaOH}+\mathrm{H}_{2} \mathrm{O}
\end{aligned}
$$

According to the stoichiometry of Equation (56), $\mathrm{Fe}(\mathrm{III})$ can react with $50 \%$ more $\mathrm{SH}^{-}$ions than $\mathrm{Fe}(\mathrm{II})$ when compared with Equation (57). The experimental data shows that $\mathrm{Fe}(\mathrm{OH})_{3}$ treats $45 \%$ more spent sulfidic sodas than $\mathrm{Fe}(\mathrm{OH})_{2}$. However, $\mathrm{Mn}(\mathrm{IV})$ was more efficient than $\mathrm{Fe}(\mathrm{III})$. $\mathrm{MnO}(\mathrm{OH})_{2}$ treated more spent sulfidic sodas than $\mathrm{Fe}(\mathrm{OH})_{3}$, which is due to the higher oxidation state of manganese. Even though the sulfur components were removed, $10 \%$ of the COD remained in the spent sulfidic caustic soda treated. The solids produced, $\mathrm{FeS}$ or $\mathrm{MnS}$, can be oxidized with hydrogen peroxide or hypochlorite at $25^{\circ} \mathrm{C}$ in an alkaline medium allowing the recovery of manganese and iron hydroxides according to the following reactions:

$$
\begin{gathered}
4 \mathrm{NaOH}+2 \mathrm{FeS} \downarrow+9 \mathrm{H}_{2} \mathrm{O}_{2} \rightarrow 8 \mathrm{H}_{2} \mathrm{O}+2 \mathrm{Na}_{2} \mathrm{SO}_{4}+2 \mathrm{Fe}(\mathrm{OH})_{3} \\
\mathrm{H}_{2} \mathrm{O}+4 \mathrm{NaOH}+2 \mathrm{FeS} \downarrow+9 \mathrm{NaOCl} \rightarrow 9 \mathrm{NaCl}+2 \mathrm{Na}_{2} \mathrm{SO}_{4}+2 \mathrm{Fe}(\mathrm{OH})_{3} \\
2 \mathrm{NaOH}+2 \mathrm{MnS} \downarrow+5 \mathrm{H}_{2} \mathrm{O}_{2} \rightarrow 5 \mathrm{H}_{2} \mathrm{O}+2 \mathrm{Na}_{2} \mathrm{SO}_{4}+2 \mathrm{MnO}(\mathrm{OH})_{2} \downarrow \\
2 \mathrm{NaOH}+2 \mathrm{MnS} \downarrow+5 \mathrm{NaOCl} \rightarrow 5 \mathrm{NaCl}+2 \mathrm{Na}_{2} \mathrm{SO}_{4}+2 \mathrm{MnO}(\mathrm{OH})_{2} \downarrow
\end{gathered}
$$

For these reactions to occur correctly, the addition of oxidants must be slow and under stirring.

The treatments based on precipitation may be of interest, as they enable the reuse of treated sulfidic sodas, which reduces the formation of effluents and the consumption of water and chemical reagents. However, considerable amounts of chemical sludges (precipitated) are produced, which are, in general, hard to dispose of.

The use of exchange resins to treat spent sulfidic sodas is very limited, although, successful results have been obtained in the treatment of SSC [94]. The application of two sturdy anion exchange resins was studied, with a matrix of styrene-divinylbenzene. The behavior of both resins was very similar to the adsorption of $21.0-22.5 \mathrm{~g} \mathrm{~S}^{2-} / \mathrm{L}$. The robust anion exchange resins hold tightly the $\mathrm{S}^{2-}$ ions, which are not moved by the $\mathrm{OH}^{-}$, even in high alkaline mediums. The $\mathrm{pH}$ adjustment to lower values is not a good practice since $\mathrm{H}_{2} \mathrm{~S}$ is released when the $\mathrm{pH}$ is adjusted under 9. Although the results were positive, the initial costs of investment must be seriously considered, as well as the maintenance costs due to the resin dirt. It would imply a process of regeneration of the resins with frequency, and, therefore, a relatively short duration time, incurring replacement costs for these materials.

Considering the diverse possibilities of use of treatment methods for spent sodas, in Figure 3 a summary is presented with the main possibilities of application of these methods according to the origin or characteristics of spent sodas. 


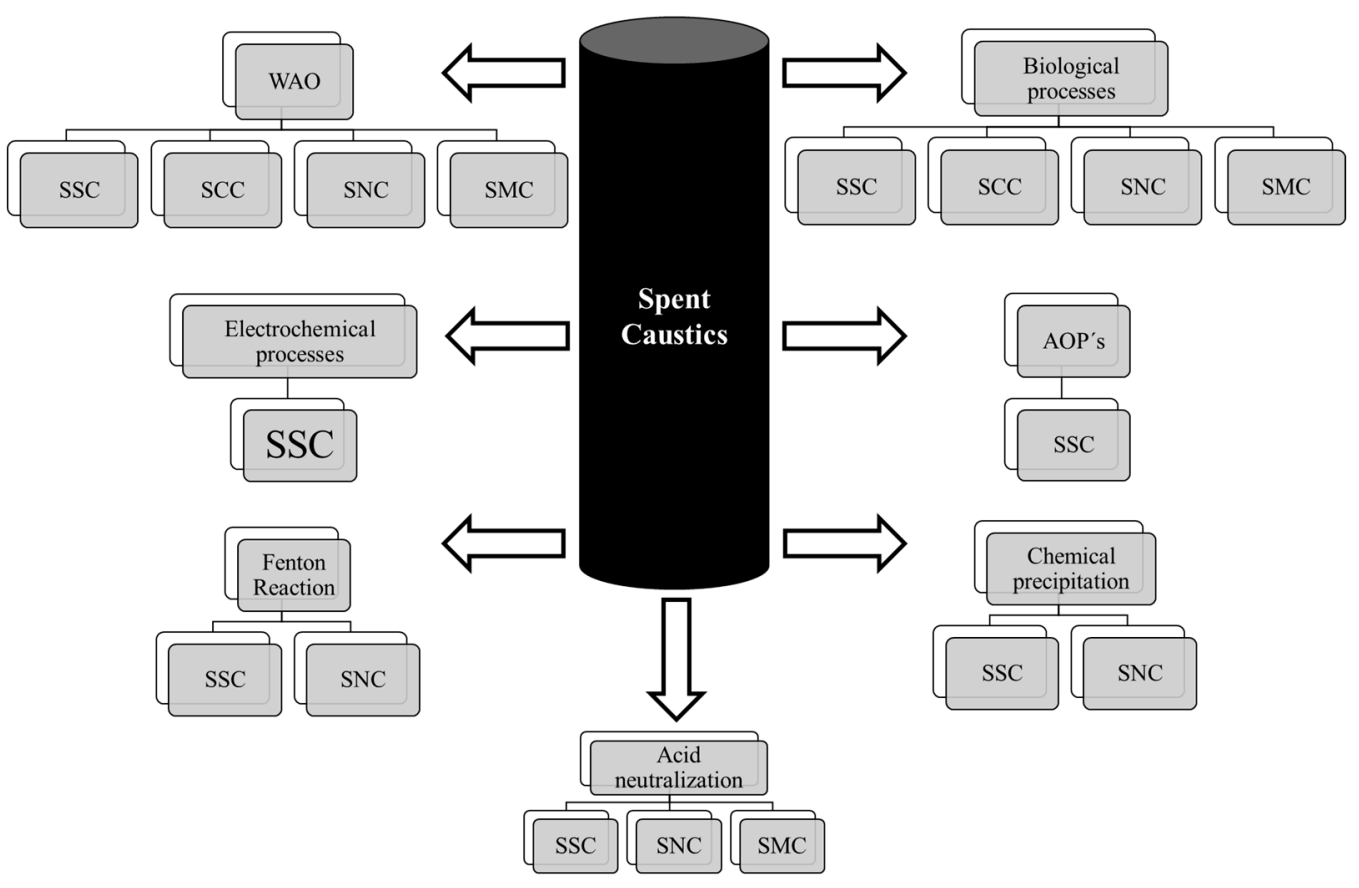

Figure 3. Application of diverse processes of spent sodas.

For the specific application of each of these methods, the subsequent biological treatment to which their effluent will be submitted is to be considered. It is essential to reconfirm that the direct application of these biological processes to the spent sodas cannot be carried out without the appropriate dilution of them.

\section{Conclusions}

The characteristics of spent sodas depend on the process where they are formed. High pollutant potential of these residues is caused by high $\mathrm{pH}$ and remarkable concentrations of sulfide compounds, mainly as a reduced form like sulfides and mercaptans. Additionally, organic compounds such as petroleum oils, phenols and benzenes, and significant amounts of salts are reported.

Wet air oxidation (WAO) is considered the safest, more resistant, and thoroughly proven technology applied at the laboratory, pilot, and plant level. The application of any of its alternatives at low, medium, and high temperatures, depends mainly on the characteristics of the spent sodas to be treated, i.e., sulfidic, naphthenic, cresylic, or a mixture of them. However, their high investment and operational costs have driven several types of research and specialists to seek other technological alternatives for the treatment of SC.

One of the technological alternatives is the Fenton process applied to refineries, as it is an option to be considered in the second level of applicability. Otherwise, acid neutralization could be applied in some cases due to the simplicity of the system. It brings advantages for low naphthenic acid content in spent sodas, for example they are separated in the process and not destroyed, as in the WAO process. A combination of this method with an advanced oxidation process or WAO at low temperatures should be assessed to replace the WAO that operates at high temperatures.

The application of processes to SC as they are produced is not possible due to its toxic characteristics. However, a combination of the correct degree of dilution and these processes is more environmentally friendly than the physical-chemical processes. Therefore, the alternative of a mixture with other waste should always be considered.

Other treatments of SC have been studied, such as electrochemical processes, precipitation, resins, and ionic liquids; they have several limitations on a real scale. Among these processes, the application of the so-called "Green Solvents" presents a new outlook. Their recovery after the treatment is still a 
problem to be solved in order to reduce the costs and residues. The electrochemical processes with membranes have also shown very positive aspects regarding their applicability for the treatment of SC. However, there are still technical scenarios to be studied in more detail and depth.

Author Contributions: E.P.-C., S.M. compiled the literature references. Writing-Original draft, S.M. Writing-Review and editing, E.P.-C., C.H., F.C., J.G. All authors have read and agreed to the published version of the manuscript.

Funding: This research received no external funding.

Acknowledgments: This work is dedicated to the memory of our well esteemed and wonderful colleague Dr. Silvio Montalvo Martínez who recently passed away. Thanks to Engineers of ENAP-Aconcagua Refinery, Chile, for their collaboration.

Conflicts of Interest: The authors declare no conflict of interest.

\section{References}

1. Abolghasem, K.; Kharaji, A.G.; Mehrabani-Zeinabad, A.; Faizi, V.; Kazemi, J.; Shariati, A. Synergy between two natural gas sweetening processes. J. Unconv. Oil Gas Resour. 2016, 14, 6-11.

2. Heidarinasab, A.; Hashemi, S.R. A study of biological treatment of spent sulfidic caustic. In Proceedings of the International Conference on Chemical, Ecology and Environmental Sciences (ICCEES'2011), Pattaya, Thailand, 17-18 December 2011.

3. Hashemi, S.R.; Heidarinasab, A. Spent Caustic Bioregeneration by using Thiobacillus denitrificans Bacteria. World Acad. Sci. Eng. Technol. 2012, 67, 417-419.

4. Hawari, A.; Ramadan, H.; Abu-Reesh, I.; Ouederni, M. A comparative study of the treatment of ethylene plant spent caustic by neutralization and classical and advanced oxidation. J. Environ. Manag. 2015, 151, 105-112. [CrossRef]

5. De Graaff, M.; Klok, J.B.M.; Bijmans, M.F.M.; Muyzer, G.; Janssen, A.J.H. Application of a 2-step process for the biological treatment of sulfidic spent caustics. Water Res. 2012, 46, 723-730. [CrossRef]

6. Conner, J.A.; Beitle, R.R.; Duncan, K.; Kolhatkar, R.; Sublette, K.L. Biotreatment of Refinery Spent-Sulfidic Caustic Using an Enrichment Culture Immobilized in a Novel Support Matrix. Appl. Biochem. Biotechnol. 2003, 84, 707-719.

7. Nasr Esfahani, K.; Farhadian, M.; Solaimany Nazar, A.R. Interaction effects of various reaction parameters on the treatment of sulfidic spent caustic through electro-photo-Fenton. Int. J. Environ. Sci. Technol. 2019, 16, 7165-7174. [CrossRef]

8. Karimi, A.; Fatehifar, E.; Alizadeh, R.; Ahadzadeh, I. Regeneration and treatment of sulfidic spent caustic using analytic hierarchy process. Environ. Heal. Eng. Manag. 2016, 3, 203-208. [CrossRef]

9. Lee, J.H.; Park, J.J.; Seo, K.S.; Choi, G.C.; Lee, T.H. Simultaneous autotrophic \& heterotrophic denitrification by the injection of reformed spent sulfidic caustic (SSC) in a pilot-scale sewage treatment plant. Korean J. Chem. Eng. 2013, 30, 139-144.

10. Al Jabari, M. Spent Caustic Treatment Using Advanced Oxidation Processes. Master's Thesis, University of Sharjah, Sharjah, UAE, 2012.

11. Veerabhadraiah, G.; Mallika, N.; Jindal, S. Spent caustic management: Remediation review. Hydrocarb. Process. 2011, 90, 41-46.

12. Park, J.J.; Byun, I.G.; Park, S.R.; Lee, J.H.; Park, S.H.; Park, T.J.; Lee, T.H. Use of spent sulfidic caustic for autotrophic denitrification in the biological nitrogen removal processes: Lab-scale and pilot-scale experiments. J. Ind. Eng. Chem. 2009, 15, 316-322. [CrossRef]

13. Alnaizy, R. Economic analysis for wet oxidation processes for the treatment of mixed refinery spent caustic. Environ. Prog. 2008, 27, 295-301. [CrossRef]

14. Duesel, B.F.; Gibbons, J.P.; Rutsch, M.J. Treatment of Spent Caustic Refinery Effluents. U.S. Patent 7,214,290, 8 May 2007.

15. Sipma, J.; Svitelskaya, A.; Van Der Mark, B.; Hulshoff Pol, L.W.; Lettinga, G.; Buisman, C.J.N.; Janssen, A.J.H. Potentials of biological oxidation processes for the treatment of spent sulfidic caustics containing thiols. Water Res. 2004, 38, 4331-4340. [CrossRef] [PubMed] 
16. Sabri, M.A.; Ibrahim, T.H.; Khamis, M.I.; Nancarrow, P.; Hassan, M.F. Spent caustic treatment using hydrophobic room temperatures ionic liquids. J. Ind. Eng. Chem. 2018, 65, 325-333. [CrossRef]

17. Ben Hariz, I.; Halleb, A.; Adhoum, N.; Monser, L. Treatment of petroleum refinery sulfidic spent caustic wastes by electrocoagulation. Sep. Purif. Technol. 2013, 107, 150-157. [CrossRef]

18. Kumfer, B.; Felch, C.; Maugans, C. Wet air oxidation treatment of spent caustic in petroleum refineries. In Proceedings of the National Petroleum Refiners Association Conference, Phoenix, AZ, USA, 21-23 March 2010; Volume 23, pp. 49-67.

19. Ahmad, W. Neutralization of Spent Caustic from LPG Plant at Preem AB Göteborg. Master's Thesis, Chalmers University of Technology, Gothenburg, Sweden, 2010.

20. Huaman, F.; Davila Villar, N. Disposal of Spent Caustic at the Repsol YPF Refinery in La Pampilla, Peru. In Proceedings of the Environmental Conference, Austin, TX, USA, 24-25 September 2007.

21. Ellis, C.E. Wet air oxidation of refinery spent caustic. Environ. Prog. 1998, 17, 28-30. [CrossRef]

22. Singh, S. Shikha Treatment and Recycling of Wastewater from Oil Refinery/Petroleum Industry. In Advances in Biological Treatment of Industrial Waste Water and their Recycling for a Sustainable Future; Springer: Singapore, 2019; pp. 303-332.

23. Tobiszewski, M.; Tsakovski, S.; Simeonov, V.; Namieśnik, J. Chlorinated solvents in a petrochemical wastewater treatment plant: An assessment of their removal using self-organising maps. Chemosphere 2012, 87, 962-968. [CrossRef]

24. Hasan, D.B.; Abdul Aziz, A.R.; Daud, W.M.A.W. Oxidative mineralisation of petroleum refinery effluent using Fenton-like process. Chem. Eng. Res. Des. 2012, 90, 298-307. [CrossRef]

25. Park, S.; Seon, J.; Byun, I.; Cho, S.; Park, T.; Lee, T. Comparison of nitrogen removal and microbial distribution in wastewater treatment process under different electron donor conditions. Bioresour. Technol. 2010, 101, 2988-2995. [CrossRef]

26. Al Zarooni, M.; Elshorbagy, W. Characterization and assessment of Al Ruwais refinery wastewater. J. Hazard. Mater. 2006, 136, 398-405. [CrossRef]

27. Copa, W.M.; Momont, J.A. Wet air oxidation of energetics and chemical agent surrogates. J. Energy Mater. 1995, 13, 235-258. [CrossRef]

28. DeAngelo, D.J.; Wilhelmi, A.R. Wet air oxidation of spent caustic liquors. Chem. Eng. Prog 1983, 79, 3.

29. Copa, W. Wet air oxidation of spent caustics. Natl. Environ. J. 1994, 4, 16-19.

30. Matthews, R. Performance update: Low pressure wet air oxidation unit at grangemouth, Scotland. Environ. Prog. 1997, 16, 9-12. [CrossRef]

31. Ellis, C.; Maugans, C.B. WAO treats spent caustic liquor in Asia and Brazil. Water Wastewater Int. 2004, 19, 35-36.

32. Huaman, F.D.; Villar, N.; Felch, C.; Maugans, C.; Olsen, S. A highly refined effort. Water Wastewater Int. 2009, 24, 28-32.

33. Chang, C.J.; Lin, J.-C.; Chen, C.-K. Effects of temperature and Cu2+ catalyst on liquid-phase oxidation of industrial wastewaters. J. Chem. Technol. Biotechnol. 1993, 57, 355-361. [CrossRef]

34. Jagushte, M.V.; Mahajani, V.V. Insight into spent caustic treatment: On wet oxidation of thiosulfate to sulfate. J. Chem. Technol. Biotechnol. 1999, 74, 437-444. [CrossRef]

35. Debellefontaine, H.; Foussard, J.N. Wet air oxidation for the treatment of industrial wastes. Chemical aspects, reactor design and industrial applications in Europe. Waste Manag. 2000, 20, 15-25. [CrossRef]

36. Seyedin, S.; Hassanzadeganroudsari, M. Evaluation of the Different Methods of Spent Caustic Treatment. Int. J. Adv. Res. Sci. Eng. Technol. 2018, 5, 5275-5283.

37. De Haan, S.; Howdeshell, M.; Maugans, C. Update: Spent caustic treatment. Hydrocarb. Process. 2010, 9, 61.

38. Kim, K.H.; Ihm, S.K. Heterogeneous catalytic wet air oxidation of refractory organic pollutants in industrial wastewaters: A review. J. Hazard. Mater. 2011, 186, 16-34. [CrossRef]

39. Zhu, W.; Bin, Y.; Li, Z.; Jiang, Z.; Yin, T. Application of catalytic wet air oxidation for the treatment of H-acid manufacturing process wastewater. Water Res. 2002, 36, 1947-1954. [CrossRef]

40. Janssen, A.J.; Lettinga, G.; Bontsema, J.; Van Straten, G.; Kuenen, J.G.; De Zwart, J.M.M. Biological Treatment of Spent Caustic. U.S. Patent 6,045,695, 4 April 2000.

41. Oliviero, L.; Barbier, J.; Duprez, D.; Guerrero-Ruiz, A.; Bachiller-Baeza, B.; Rodríguez-Ramos, I. Catalytic wet air oxidation of phenol and acrylic acid over $\mathrm{Ru} / \mathrm{C}$ and $\mathrm{Ru}-\mathrm{CeO} 2 / \mathrm{C}$ catalysts. Appl. Catal. B Environ. 2000, 25, 267-275. [CrossRef] 
42. Lei, L.; Hu, X.; Chu, H.P.; Chen, G.; Yue, P.L. Catalytic wet air oxidation of dyeing and printing wastewater. Water Sci. Technol. 1997, 35, 311-319. [CrossRef]

43. Núñez, F.; Del Angel, G.; Tzompantzi, F.; Navarrete, J. Catalytic Wet-Air Oxidation of p-Cresol on $\mathrm{Ag} / \mathrm{Al}_{2} \mathrm{O}_{3}-\mathrm{ZrO}_{2}$ Catalysts. Ind. Eng. Chem. Res. 2011, 50, 2495-2500. [CrossRef]

44. Zermeño-Montante, I.; Nieto-Delgado, C.; Sagredo-Puente, R.D.; Cárdenas-Galindo, M.G.; Handy, B.E. Catalytic Wet Air Oxidation of Sodium Sulfide Solutions. Effect of the Metal-Support and Acidity of the Catalysts. Top. Catal. 2011, 54, 579-586. [CrossRef]

45. Barge, A.S.; Vaidya, P.D. Kinetics of wet air oxidation of sodium sulfide over heterogeneous iron catalyst. Int. J. Chem. Kinet. 2019, 52, 92-98. [CrossRef]

46. Barge, A.S.; Vaidya, P.D. Wet air oxidation of cresylic spent caustic-A model compound study over graphene oxide (GO) and ruthenium/GO catalysts. J. Environ. Manag. 2018, 212, 479-489. [CrossRef]

47. Sheu, S.H.; Weng, H.S. Treatment of olefin plant spent caustic by combination of neutralization and fenton reaction. Water Res. 2001, 35, 2017-2021. [CrossRef]

48. Wang, S.; Liu, X.; Zhang, M. Reduction of Ammineruthenium(III) by Sulfide Enables In Vivo Electrochemical Monitoring of Free Endogenous Hydrogen Sulfide. Anal. Chem. 2017, 89, 5382-5388. [CrossRef]

49. Nuñez, P.; Hansen, H.K.; Rodriguez, N.; Guzman, J.; Gutierrez, C. Electrochemical Generation of Fenton's Reagent to Treat Spent Caustic Wastewater. Sep. Sci. Technol. 2009, 44, 2223-2233. [CrossRef]

50. Oprea, F.; Fendu, E.-M.; Nicolae, M.; Pantea, O.; Dunka, M. Experimental studies concerning treatment of the spent caustic solutions from refineries MEROX and EXOMER units. Rev. Chim. 2010, 61, 608-661.

51. Poyatos, J.M.; Muñio, M.M.; Almecija, M.C.; Torres, J.C.; Hontoria, E.; Osorio, F. Advanced oxidation processes for wastewater treatment: State of the art. Water Air Soil Pollut. 2010, 205, 187-204. [CrossRef]

52. Oller, I.; Malato, S.; Sánchez-Pérez, J.A. Combination of Advanced Oxidation Processes and biological treatments for wastewater decontamination-A review. Sci. Total Environ. 2011, 409, 4141-4166. [CrossRef]

53. Shon, H.K.; Vigneswaran, S.; Snyder, S.A. Effluent organic matter (EfOM) in wastewater: Constituents, effects, and treatment. Crit. Rev. Environ. Sci. Technol. 2006, 36, 327-374. [CrossRef]

54. Andreozzi, R.; Caprio, V.; Insola, A.; Marotta, R. Advanced oxidation processes (AOP) for water purification and recovery. Catal. Today 1999, 53, 51-59. [CrossRef]

55. Mabury, S. Hydroxyl Radical in Natural Waters. Ph.D. Thesis, University of California, Davis, CA, USA, 1993.

56. Gurol, M.D.; Vatistas, R. Oxidation of phenolic compounds by ozone and ozone + u.v. radiation: A comparative study. Water Res. 1987, 21, 895-900. [CrossRef]

57. Yu, Z.-Z.; Sun, D.-Z.; Li, C.-H.; Shi, P.-F.; Duan, X.-D.; Sun, G.-R.; Liu, J.-X. UV-catalytic treatment of spent caustic from ethene plant with hydrogen peroxide and ozone oxidation. J. Environ. Sci. 2004, 16, 272-275.

58. Alaton, I.A.; Balcioglu, I.A.; Bahnemann, D.W. Advanced oxidation of a reactive dyebath effluent: Comparison of $\mathrm{O}_{3}, \mathrm{H}_{2} \mathrm{O}_{2} / \mathrm{UV}-\mathrm{C}$ and $\mathrm{TiO}_{2} / \mathrm{UV}-\mathrm{A}$ processes. Water Res. 2002, 36, 1143-1154. [CrossRef]

59. Gottschalk, C.; Libra, J.A.; Saupe, A. Ozonation of Water and Waste Water: A Practical Guide to Understanding Ozone and Its Applications; John Wiley \& Sons: Hoboken, NJ, USA, 2008; ISBN 9783527613342.

60. Hernández, F.; Geissler, G. Photooxidative Treatment of Sulfurous Water for Its Potabilization. Photochem. Photobiol. 2005, 81, 636.

61. Glaze, W.H.; Kang, J.W.; Chapin, D.H. The chemistry of water treatment processes involving ozone, hydrogen peroxide and ultraviolet radiation. Ozone Sci. Eng. 1987, 9, 335-352. [CrossRef]

62. Yonar, T.; Yonar, G.K.; Kestioglu, K.; Azbar, N. Decolorisation of textile effluent using homogeneous photochemical oxidation processes. Color. Technol. 2005, 121, 258-264. [CrossRef]

63. Shemer, H.; Narkis, N. Trihalomethanes aqueous solutions sono-oxidation. Water Res. 2005, 39, $2704-2710$. [CrossRef]

64. Fan, X.; Hao, H.; Shen, X.; Chen, F.; Zhang, J. Removal and degradation pathway study of sulfasalazine with Fenton-like reaction. J. Hazard. Mater. 2011, 190, 493-500. [CrossRef]

65. Neyens, E.; Baeyens, J. A review of classic Fenton's peroxidation as an advanced oxidation technique. J. Hazard. Mater. 2003, 98, 33-50. [CrossRef]

66. Bianco, B.; De Michelis, I.; Vegliò, F. Fenton treatment of complex industrial wastewater: Optimization of process conditions by surface response method. J. Hazard. Mater. 2011, 186, 1733-1738. [CrossRef]

67. Isarain-Chávez, E.; Rodríguez, R.M.; Garrido, J.A.; Arias, C.; Centellas, F.; Cabot, P.L.; Brillas, E. Degradation of the beta-blocker propranolol by electrochemical advanced oxidation processes based on Fenton's reaction chemistry using a boron-doped diamond anode. Electrochim. Acta 2010, 56, 215-221. [CrossRef] 
68. Lipczynska-Kochany, E.; Sprah, G.; Harms, S. Influence of some groundwater and surface waters constituents on the degradation of 4-chlorophenol by the Fenton reaction. Chemosphere 1995, 30, 9-20. [CrossRef]

69. Vilve, M.; Hirvonen, A.; Sillanpää, M. Effects of reaction conditions on nuclear laundry water treatment in Fenton process. J. Hazard. Mater. 2009, 164, 1468-1473. [CrossRef]

70. Kulik, N.; Trapido, M.; Goi, A.; Veressinina, Y.; Munter, R. Combined chemical treatment of pharmaceutical effluents from medical ointment production. Chemosphere 2008, 70, 1525-1531. [CrossRef]

71. Kang, Y.W.; Hwang, K.-Y. Effects of reaction conditions on the oxidation efficiency in the Fenton process. Water Res. 2000, 34, 2786-2790. [CrossRef]

72. El-Naas, M.H.; Al-Zuhair, S.; Al-Lobaney, A.; Makhlouf, S. Assessment of electrocoagulation for the treatment of petroleum refinery wastewater. J. Environ. Manag. 2009, 91, 180-185. [CrossRef]

73. Tezcan Un, U.; Koparal, A.S.; Bakir Ogutveren, U. Electrocoagulation of vegetable oil refinery wastewater using aluminum electrodes. J. Environ. Manag. 2009, 90, 428-433. [CrossRef]

74. Vepsalainen, M.; Selin, J.; Rantala, P.; Pulliainen, M.; Sarkka, H.; Kuhmonen, K.; Bhatnagar, A.; Sillanpaa, M. Precipitation of dissolved sulphide in pulp and paper mill wastewater by electrocoagulation. Environ. Technol. 2011, 32, 1393-1400. [CrossRef]

75. Asselin, M.; Drogui, P.; Brar, S.K.; Benmoussa, H.; Blais, J.-F. Organics removal in oily bilgewater by electrocoagulation process. J. Hazard. Mater. 2008, 151, 446-455. [CrossRef]

76. Moreno-Casillas, H.A.; Cocke, D.L.; Gomes, J.A.G.; Morkovsky, P.; Parga, J.R.; Peterson, E. Electrocoagulation mechanism for COD removal. Sep. Purif. Technol. 2007, 56, 204-211. [CrossRef]

77. Kabay, N.; Demircioglu, M.; Ersöz, E.; Kurucaovali, I. Removal of calcium and magnesium hardness by electrodialysis. Desalination 2002, 149, 343-349. [CrossRef]

78. Kumar, M.; Tripathi, B.P.; Saxena, A.; Shahi, V.K. Electrochemical membrane reactor: Synthesis of quaternary ammonium hydroxide from its halide by in situ ion substitution. Electrochim. Acta 2009, 54, 1630-1637. [CrossRef]

79. Feng, H.; Huang, C.; Xu, T. Production of Tetramethyl Ammonium Hydroxide Using Bipolar Membrane Electrodialysis. Ind. Eng. Chem. Res. 2008, 47, 7552-7557. [CrossRef]

80. Wei, Y.; Wang, Y.; Zhang, X.; Xu, T. Comparative study on regenerating sodium hydroxide from the spent caustic by bipolar membrane electrodialysis (BMED) and electro-electrodialysis (EED). Sep. Purif. Technol. 2013, 118, 1-5. [CrossRef]

81. Kubo, D.; Kawase, Y. Hydroxyl radical generation in electro-Fenton process with in situ electro-chemical production of Fenton reagents by gas-diffusion-electrode cathode and sacrificial iron anode. J. Clean. Prod. 2018, 203, 685-695. [CrossRef]

82. Davarnejad, R.; Bakhshandeh, M. Olefin plant spent caustic wastewater treatment using electro-Fenton technique. Egypt. J. Pet. 2018, 27, 573-581. [CrossRef]

83. Guerrero, L.; Montalvo, S.; Huiliñir, C.; Campos, J.L.; Barahona, A.; Borja, R. Advances in the biological removal of sulphides from aqueous phase in anaerobic processes: A review. Environ. Rev. 2015, 24, 84-100. [CrossRef]

84. Sawasdee, V.; Pisutpaisal, N. Simultaneous pollution treatment and electricity generation of tannery wastewater in air-cathode single chamber MFC. Int. J. Hydrogen Energy 2016, 41, 15632-15637. [CrossRef]

85. Logan, B.E.; Rabaey, K. Conversion of wastes into bioelectricity and chemicals by using microbial electrochemical technologies. Science 2012, 337, 686-690. [CrossRef]

86. Fazli, N.; Mutamim, N.S.A.; Jafri, N.M.A.; Ramli, N.A.M. Microbial Fuel Cell (MFC) in treating spent caustic wastewater: Varies in Hydraulic Retention Time (HRT) and Mixed Liquor Suspended Solid (MLSS). J. Environ. Chem. Eng. 2018, 6, 4339-4346. [CrossRef]

87. Keramati, N.; Moheb, A.; Ehsani, M.R. Effect of operating parameters on NaOH recovery from waste stream of Merox tower using membrane systems: Electrodialysis and electrodeionization processes. Desalination 2010, 259, 97-102. [CrossRef]

88. Delgado Vela, J.; Dick, G.J.; Love, N.G. Sulfide inhibition of nitrite oxidation in activated sludge depends on microbial community composition. Water Res. 2018, 138, 241-249. [CrossRef]

89. De Graaff, M.; Bijmans, M.F.M.; Abbas, B.; Euverink, G.-J.W.; Muyzer, G.; Janssen, A.J.H. Biological treatment of refinery spent caustics under halo-alkaline conditions. Bioresour. Technol. 2011, 102, 7257-7264. [CrossRef]

90. Rajganesh, B.; Sublette, K.L.; Camp, C.; Richardson, M.R. Biotreatment of Refinery Spent Sulfidic Caustics. Biotechnol. Prog. 1995, 11, 228-230. [CrossRef] 
91. Gholipour, S.; Mehrkesh, P.; Azin, E.; Nouri, H.; Rouhollahi, A.A.; Moghimi, H. Biological treatment of toxic refinery spent sulfidic caustic at low dilution by sulfur-oxidizing fungi. J. Environ. Chem. Eng. 2018, 6, 2762-2767. [CrossRef]

92. Welton, T. Room-Temperature Ionic Liquids. Solvents for Synthesis and Catalysis. Chem. Rev. 1999, 99, 2071-2084. [CrossRef] [PubMed]

93. Abulhassani, J.; Manzoori, J.L.; Amjadi, M. Hollow fiber based-liquid phase microextraction using ionic liquid solvent for preconcentration of lead and nickel from environmental and biological samples prior to determination by electrothermal atomic absorption spectrometry. J. Hazard. Mater. 2010, 176, 481-486. [CrossRef] [PubMed]

94. Paulino, J.F.; Afonso, J.C. New strategies for treatment and reuse of spent sulfidic caustic stream from petroleum industry. Química Nov. 2012, 35, 1447-1452. [CrossRef]

(C) 2020 by the authors. Licensee MDPI, Basel, Switzerland. This article is an open access article distributed under the terms and conditions of the Creative Commons Attribution (CC BY) license (http://creativecommons.org/licenses/by/4.0/). 